\title{
Impact of over-exploitation on groundwater quality: A case study from WR-2 Watershed, India
}

\author{
Anil M Pophare ${ }^{1, *}$, Bhushan R Lamsoge ${ }^{2}$, Yashwant B Katpatal ${ }^{3}$ and Vijay P Nawale ${ }^{4}$ \\ ${ }^{1}$ Department of Geology, RTM Nagpur University, Nagpur 440 001, India. \\ ${ }^{2}$ Central Ground Water Board, Nagpur 440 001, India. \\ ${ }^{3}$ Visvesvaraya National Institute of Technology, Nagpur 440 010, India. \\ ${ }^{4}$ Geological Survey of India, Hyderabad, India. \\ ${ }^{*}$ Corresponding author. e-mail: apophare@gmail.com
}

The WR-2 watershed is located in the Deccan trap basaltic terrain of Maharashtra State, India. The watershed area incorporates a rich orange orchard belt that requires a huge quantity of water for irrigation. This requirement is mostly met through groundwater, extracted from the shallow aquifers of the WR-2 watershed. However, over the years, excess withdrawal of groundwater from these aquifers has resulted in depletion of groundwater level. The declining trends of groundwater level, both long term and short term, have had a negative impact on the groundwater quality of the study area. This effect can be gauged through the rising electrical conductivity (EC) of groundwater in the shallow aquifers (dug wells) of the WR-2 watershed. It is observed that the long term declining trend of groundwater level, during 1977-2010, varied from 0.03 to $0.04 \mathrm{~m}$ per year, whereas the corresponding trend of rising EC varied from 1.90 to $2.94 \mu \mathrm{S} / \mathrm{cm}$ per year. During 2007-2010, about 56\% dug wells showed a positive correlation between depleting groundwater level and rising EC values. The groundwater level depletion during this period ranged from 0.03 to $0.67 \mathrm{~m}$ per year, whereas the corresponding trend of rising EC ranged from 0.52 to $46.91 \mu \mathrm{S} / \mathrm{cm}$ per year. Moreover, the water quality studies reveal that groundwater from more than $50 \%$ of the dug wells of the WR-2 watershed is not suitable for drinking purpose. The groundwater, though mostly suitable for irrigation purpose, is corrosive and saturated with respect to mineral equilibrium and shows a tendency towards chemical scale formation.

\section{Introduction}

Groundwater resources play a major role in the social and economic growth of any country. Groundwater overdraft, a form of 'over-exploitation', occurs when extraction exceeds both natural and induced aquifer recharge over a long period. Adverse effects of groundwater overdraft include, uneconomic pumping conditions, water quality degradation through induced intrusion of saline or poor quality groundwater, flow reduction in streams, wetlands and springs, land subsidence, interference with pre-existing water uses and water rights, and gradual depletion of groundwater storage. Consistent lowering of water table can dry up wells, drain springs and wetlands, and turn perennial streams into desert washes (Sophocleous 2003; Zekster et al. 2005; Harou and Lund 2008).

The global scenario of groundwater overdraft indicates that over-exploitation of groundwater from the shallow aquifers has deteriorated its quality. For example, in the alluvial Pleistocene wells of Jericho area, Palestine, groundwater overdraft has led to high salinity and high susceptibility to

Keywords. Groundwater; over-exploitation; groundwater quality; WR-2 watershed; India. 
contamination of groundwater sources due to anthropogenic influences of agricultural backflow and sewage effluent (Khayat et al. 2006). In the aquifers of Zakynthos Island, Ionian Sea, Greece, the total abstraction of groundwater exceeded natural recharge, during the last decade, resulting in saline water intrusion and deterioration of groundwater quality (Diamantopoulou and Voudouris 2008). The hydrographs and water quality trends for key aquifers in Jordan indicate a strong relationship between depleting water levels and deterioration, stemming from groundwater overdraft, point and non-point source contamination from agriculture, industrial and domestic uses also being a major problem (El-Naqa and Al-Shayeb 2009). In the Kerman province of SE Iran, over-exploitation of groundwater from the Sirjan watershed has led to significant drop in groundwater level, at an average rate of $70 \mathrm{~cm} /$ year from 1984 to 2005 . This has resulted in greater saltwater interface in the freshwater aquifers and caused deterioration of groundwater quality in a major part of the Sirjan watershed (Bagher and Rasoul 2010).

In India, over-development of groundwater resources resulted in water level depletion, shortage in water supply, worsening groundwater quality, and intrusion of saline water in coastal areas (Sivasankar et al. 2012). These factors have serious implications on the environment and socioeconomic conditions of the populace. About $85 \%$ of rural population and $\sim 50 \%$ of urban population in India is directly dependent on groundwater for their drinking, domestic, and irrigation needs. Moreover, during the last few decades, the demand of groundwater as a reliable source for fulfilling these requirements has increased manifold (CGWB 2007). Thus, the increased need of water for various purposes has culminated in excessive withdrawal of groundwater from all sources beyond the perennial yield of many watersheds. The impact of over-exploitation of groundwater resources on its quantity and quality can be witnessed in many leading states, including Maharashtra, where the agricultural productivity has been downgraded.

In Maharashtra, about $82 \%$ of the rural population is directly dependent on groundwater for irrigation, drinking, and domestic purposes. The total rechargeable fresh groundwater resources in the state are computed as 35.79 billion cubic meters (BCM), whereas the net groundwater availability is to the tune of $33.91 \mathrm{BCM}$. The present annual gross draft of groundwater in the state, for all purposes, is $17.00 \mathrm{BCM}$. Out of this about 15.95 BCM of groundwater is used for irrigation purposes and the rest for drinking and domestic uses. This quantum of groundwater for irrigation is extracted through 1.87 million abstraction structures throughout the state. These structures include 1.68 million dug wells (with mhot and pump sets) extracting 14.44 BCM of groundwater and 0.19 million bore-wells extracting 1.51 BCM of groundwater, annually. There are totally 1531 watersheds in Maharashtra and the groundwater development has reached more than $100 \%$ in most of these watersheds, as compared to groundwater recharge. This has resulted in depleting groundwater levels during either post or pre-monsoon seasons or both, such that out of the total, 66 watersheds have been categorised as over-exploited (GEC 1997; CGWB 1998a, b, 1999; CGWB and GSDA 2005, 2009; Duraiswami 2007, 2008). This scenario demands an urgent need for sustainable development of groundwater resources in the state and this requires an understanding of its origin and renewability.

The present study was carried out in one such over-exploited watershed 'WR-2', which is located in the basaltic terrain of the Eastern Deccan Volcanic Province of Vidharbha region in Maharashtra. The areal extent of the watershed incorporates a rich orange orchard belt that requires a huge quantity of water for irrigation. Due to limited availability of surface water in this area, the groundwater is extensively utilised for irrigation, domestic, and industrial purposes. Use of groundwater particularly for irrigation of orange cultivation and other agricultural practices is quite rampant. This is increasing at an alarming proportion due to the recent increase in the orange orchards in this area, resulting in over-exploitation of groundwater and depletion of water level in the shallow aquifers. It has been observed that the groundwater draft is more than the natural recharge; hence these unconfined shallow aquifers are under continual stress of water level decline and overexploitation. Groundwater development in WR-2 watershed has reached $156 \%$, leading to its categorisation as over-exploited watershed (GEC 1997; CGWB 1998a, b, 1999; CGWB and GSDA 2005, 2009). Moreover, the impact of over-exploitation of groundwater on its overall quality is quite significant, which is reflected by the rising electrical conductivity (EC) of groundwater in the dug wells of the study area. Although, there are many water conservation structures constructed in this area by various Govt. agencies and non-governmental organisations (NGOs) for restoring the water level, the benefits of these structures do not reflect on the overall groundwater scenario of the study area (CGWB 2012). Hence, in order to study, ascertain, and correlate the depleting groundwater levels, due to over-exploitation, and its impact on deteriorating groundwater quality, hydrogeological and hydrochemical investigations were carried out in the study area. 


\section{Study area}

The WR-2 watershed is located in the Warud taluka of Amravati district, Maharashtra State, India. It extends for $\sim 30 \mathrm{~km}$ from north to south and $\sim 28 \mathrm{~km}$ from east to west and has an areal extent of about $632 \mathrm{~km}^{2}$ (figure 1). It is bounded by latitudes $21^{\circ} 19^{\prime} 36^{\prime \prime}: 21^{\circ} 35^{\prime} 26^{\prime \prime}$ and longitudes $78^{\circ} 05^{\prime} 00^{\prime \prime}: 78^{\circ} 22^{\prime} 18^{\prime \prime}$, and is covered under the Survey of India Topographical Sheet Nos. $55 \mathrm{~K} / 2,55$ $\mathrm{K} / 3,55 \mathrm{~K} / 6$ and $55 \mathrm{~K} / 7$. This watershed constitutes a part of Wardha river sub-basin and is located along the surface water divide between Wardha river sub-basin and Purna river sub-basin (figure 2) (CGWB 1998a). It has a general slope of 10-20 m per km, from north to south.

The WR-2 watershed is bounded by the Satpura hill ranges towards the north while Wardha river flows along its southern boundary, from east to west. The watershed is mainly covered by a thick pile of Deccan Trap basaltic lava flows with associated intertrappean sediments of Cretaceous-Lower Eocene age and Wardha river alluvial deposits of Recent to Quaternary age. The alluvium deposits occur along the Wardha river course towards the southern part of the WR-2 watershed. They have a thickness of about 10 to $30 \mathrm{~m}$ and consist of detrital material like sand and silt with admixture of clay,

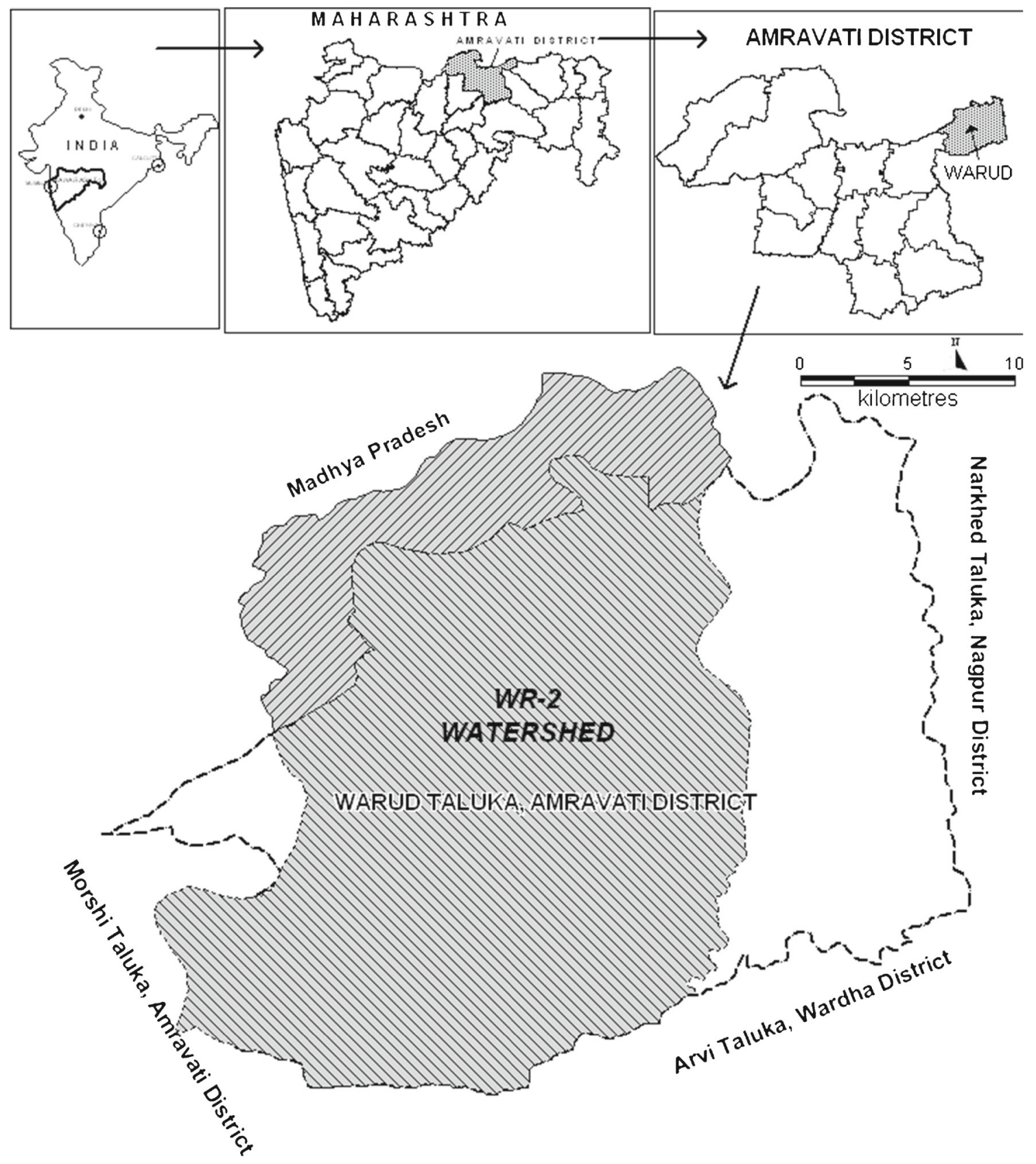

Figure 1. Location map of WR-2 watershed. 


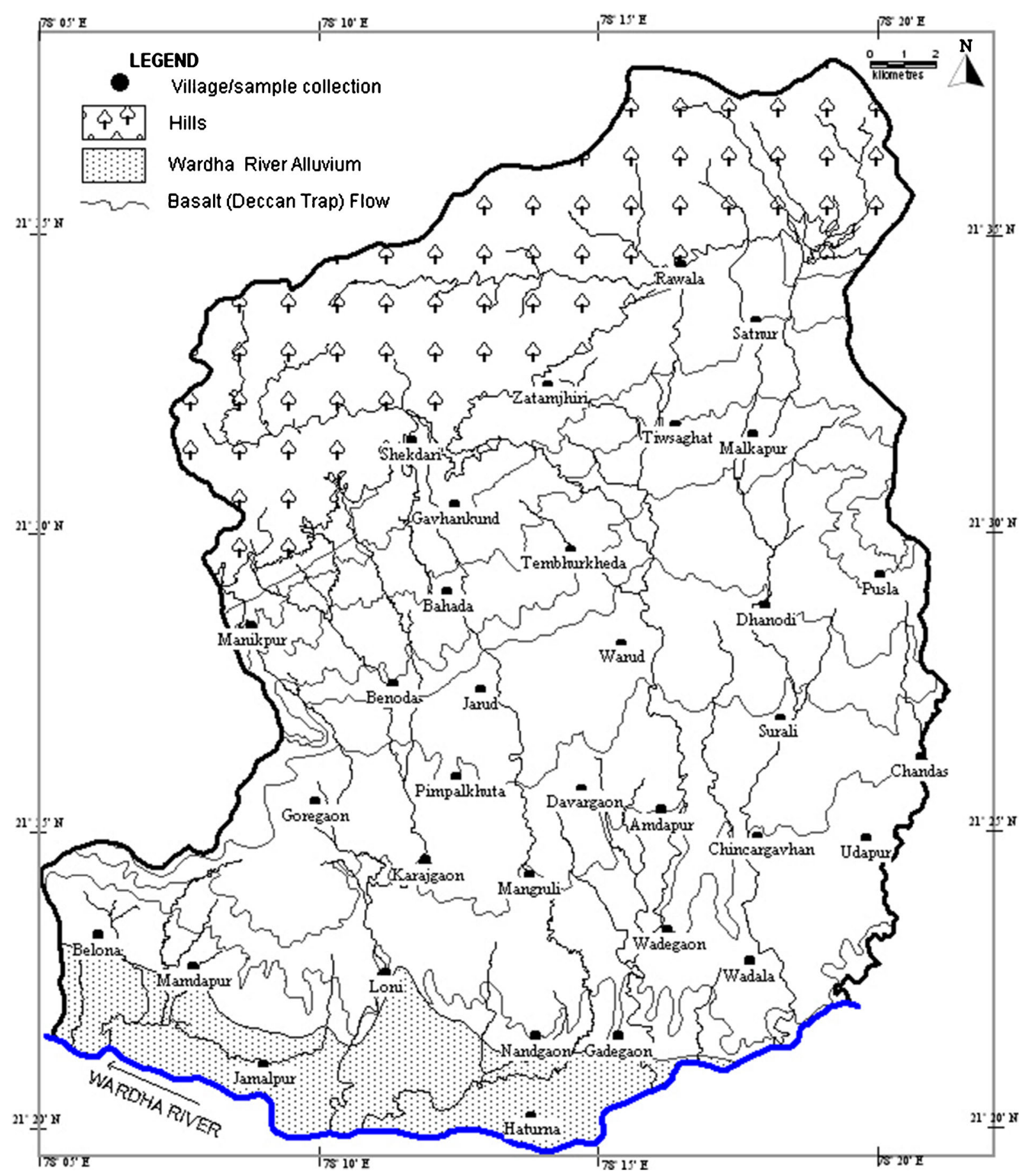

Figure 2. Generalised geological map of WR-2 watershed with village/dugwell locations.

with a few kankers forming badland topography (figure 2). About 2-m thick black cotton soil with occasional calcareous kankers envelop the basaltic terrain of this watershed (CGWB 1998a). The study area of WR-2 watershed falls under assured rainfall zone with nearly 55 rainy days and an average annual rainfall of $691 \mathrm{~mm}$. This area experiences subtropical to tropical temperate monsoon climate (CGWB 1998a, 2010).

\section{Methodology}

In the WR-2 watershed area, the water requirement of the local populace for irrigation and domestic usage is met through dug wells located on the phreatic shallow aquifers. These dug wells are hosted in jointed, fractured, vesicular, and weathered Deccan Trap basalts and Wardha river alluvium deposits. Hence, during the present study, 


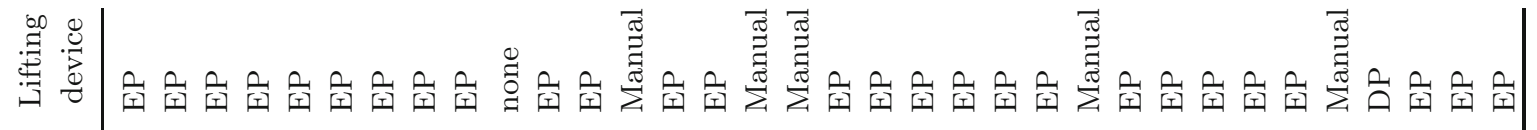

(1) ค ค - - -

$\overrightarrow{0}$.

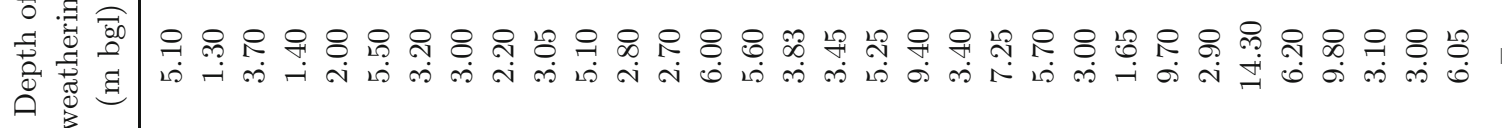

$\dot{\phi}$

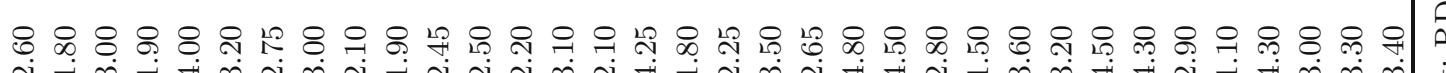

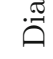

돈

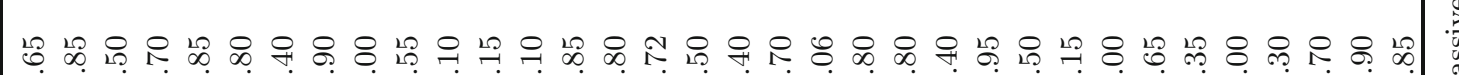

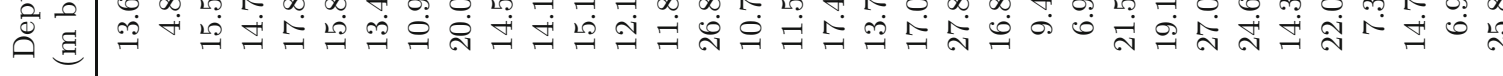

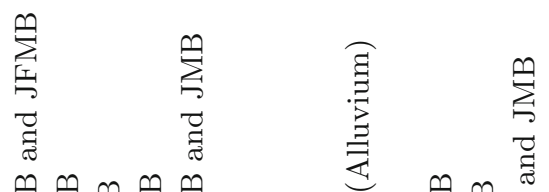

离兽

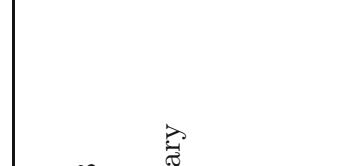

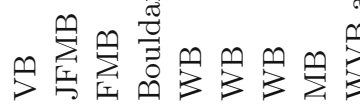

要

$\stackrel{0}{\stackrel{2}{\sim}}$

भ ำ 두

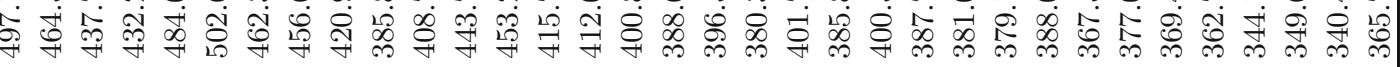

$=-1, \bar{c}=$

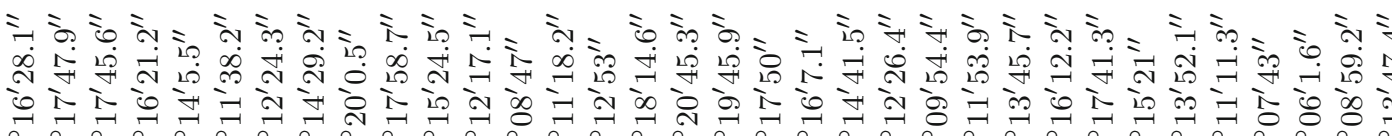

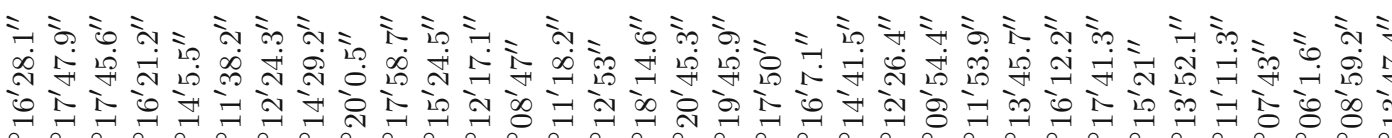

is

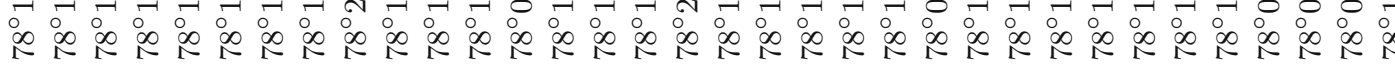

\%

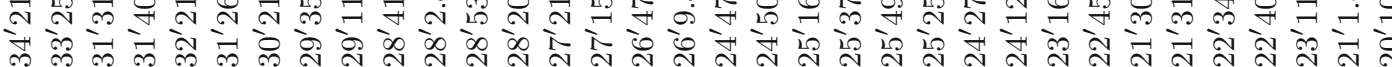

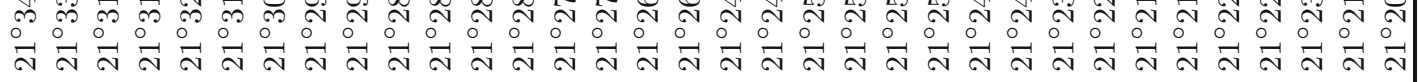

\section{更}

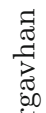

$\sum_{i}^{n} \sum_{i}^{n} \sum_{i}^{n} s_{>}^{n}$

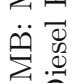

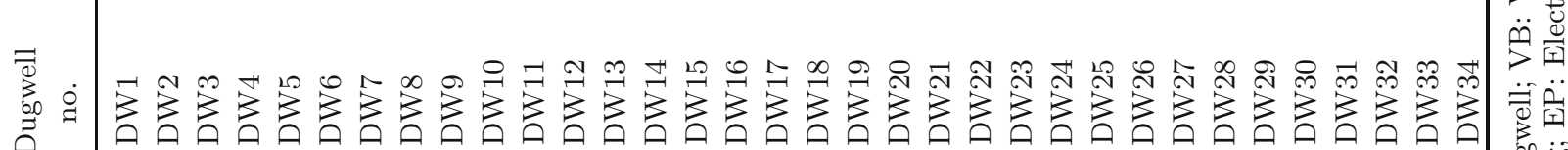
ด 
Table 2. DTWL and spot/field EC data from the key dug wells of WR-2 watershed.

\begin{tabular}{|c|c|c|c|c|c|c|c|c|c|c|c|c|c|}
\hline $\begin{array}{l}\text { Dugwell } \\
\text { no. }\end{array}$ & Parameters & $\begin{array}{l}\text { May } \\
2007\end{array}$ & $\begin{array}{l}\text { Nov } \\
2007\end{array}$ & $\begin{array}{c}\text { Jan } \\
2008\end{array}$ & $\begin{array}{l}\text { May } \\
2008\end{array}$ & $\begin{array}{l}\text { Aug } \\
2008\end{array}$ & $\begin{array}{l}\text { Nov } \\
2008\end{array}$ & $\begin{array}{c}\text { Jan } \\
2009\end{array}$ & $\begin{array}{l}\text { May } \\
2009\end{array}$ & $\begin{array}{l}\text { Aug } \\
2009\end{array}$ & $\begin{array}{l}\text { Nov } \\
2009\end{array}$ & $\begin{array}{c}\text { Jan } \\
2010\end{array}$ & $\begin{array}{l}\text { May } \\
2010\end{array}$ \\
\hline \multirow[t]{2}{*}{ DW1 } & DTWL & 12.5 & 7.65 & 10.80 & 12.05 & 11.10 & 11.70 & 10.30 & Dry & 9.50 & 6.20 & 10.60 & 11.25 \\
\hline & EC & 500 & 900 & 500 & 600 & 600 & 600 & 600 & Dry & 700 & 800 & 700 & 700 \\
\hline \multirow[t]{2}{*}{ DW2 } & DTWL & 3.85 & 2.90 & 3.30 & 3.90 & 2.95 & 3.40 & 4.50 & 7.80 & 3.05 & 2.85 & 5.10 & 5.35 \\
\hline & $\mathrm{EC}$ & 300 & 500 & 300 & 400 & 500 & 500 & 900 & 600 & 700 & 850 & 700 & 500 \\
\hline \multirow[t]{2}{*}{ DW3 } & DTWL & 15.15 & 6.10 & 10.20 & 7.95 & 4.50 & 6.50 & 8.60 & 12.70 & 4.80 & 5.00 & 8.80 & 9.10 \\
\hline & $\mathrm{EC}$ & 400 & 600 & 400 & 600 & 600 & 500 & 600 & 700 & 700 & 800 & 750 & 640 \\
\hline \multirow[t]{2}{*}{ DW4 } & DTWL & Dry & Dry & 7.40 & 12.35 & 10.35 & 10.65 & 11.50 & 14.6 & 9.40 & 6.20 & 12.35 & 13.85 \\
\hline & $\mathrm{EC}$ & NA & NA & NA & 1300 & 1300 & 600 & 1200 & 1100 & 1300 & 1470 & 1200 & 640 \\
\hline \multirow[t]{2}{*}{ DW5 } & DTWL & 17.30 & 3.90 & 6.20 & 10.90 & Dry & 11.00 & Dry & Dry & 10.35 & 8.80 & Dry & Dry \\
\hline & $\mathrm{EC}$ & 300 & 600 & 300 & 500 & NA & 500 & NA & NA & 600 & 620 & NA & NA \\
\hline \multirow[t]{2}{*}{ DW6 } & DTWL & 8.48 & 6.50 & 8.40 & 8.10 & 7.60 & 6.80 & 9.80 & 15.10 & 5.50 & 6.40 & 11.25 & 13.3 \\
\hline & $\mathrm{EC}$ & 300 & 400 & 300 & 500 & 400 & 400 & 900 & 400 & 600 & 540 & 600 & 490 \\
\hline \multirow[t]{2}{*}{ DW7 } & DTWL & 9.55 & 5.30 & 4.50 & 7.54 & 8.80 & 7.90 & 9.50 & 11.8 & 11.25 & 10.20 & 9.65 & 10.20 \\
\hline & $\mathrm{EC}$ & 400 & 600 & 400 & 1100 & 600 & 500 & 600 & 600 & 600 & 550 & 600 & 570 \\
\hline \multirow[t]{2}{*}{ DW8 } & DTWL & 10.78 & 3.00 & 4.60 & 6.80 & 4.50 & 5.55 & 8.35 & 8.20 & 5.85 & 5.80 & 8.10 & 10.4 \\
\hline & $\mathrm{EC}$ & 1200 & 1600 & 1200 & 1500 & 1300 & 1400 & 1200 & 1100 & 1200 & 1400 & 1300 & 1190 \\
\hline \multirow[t]{2}{*}{ DW9 } & DTWL & Dry & Dry & 10.10 & 13.40 & 4.40 & 11.25 & Dry & 13.90 & 4.85 & 5.00 & 11.35 & 18.90 \\
\hline & $\mathrm{EC}$ & NA & NA & NA & 600 & 400 & 700 & NA & 600 & 500 & 800 & 700 & 460 \\
\hline \multirow[t]{2}{*}{ DW10 } & DTWL & Dry & Dry & 11.2 & 11.8 & 10.3 & 12.9 & 13.45 & 14.6 & 10.95 & 10.45 & 11.7 & 12.25 \\
\hline & $\mathrm{EC}$ & NA & NA & NA & 700 & 1000 & 900 & 900 & 800 & 1100 & 1200 & 1000 & 910 \\
\hline \multirow[t]{2}{*}{ DW11 } & DTWL & 13.10 & 8.80 & 9.80 & 11.55 & 10.20 & 10.50 & 11.20 & 13.90 & 12.30 & 10.60 & 11.77 & 14.00 \\
\hline & $\mathrm{EC}$ & 1300 & 400 & 1300 & 1100 & 600 & 1000 & 1200 & 1200 & 800 & 700 & 1100 & 1350 \\
\hline \multirow[t]{2}{*}{ DW12 } & DTWL & 12.65 & 3.80 & 6.55 & 9.50 & 7.90 & 8.60 & 11.20 & Dry & 11.80 & 7.80 & 12.35 & 14.10 \\
\hline & $\mathrm{EC}$ & 700 & 900 & 700 & 900 & 900 & 800 & 800 & NA & 900 & 960 & 900 & 830 \\
\hline \multirow[t]{2}{*}{ DW13 } & DTWL & Dry & Dry & 2.95 & 9.65 & 4.15 & 4.70 & 7.45 & 12.10 & 4.90 & 4.70 & 8.50 & 11.85 \\
\hline & $\mathrm{EC}$ & NA & NA & NA & 700 & 800 & 700 & 700 & 700 & 900 & 790 & 800 & 740 \\
\hline \multirow[t]{2}{*}{ DW14 } & DTWL & 9.80 & 5.35 & 7.95 & 9.05 & 7.55 & 7.75 & 8.35 & 11.35 & 7.10 & 6.15 & 8.35 & 10.40 \\
\hline & $\mathrm{EC}$ & 1100 & 800 & 1100 & 700 & 700 & 500 & 600 & 600 & 700 & 640 & 600 & 650 \\
\hline \multirow[t]{2}{*}{ DW15 } & DTWL & 16.45 & 8.90 & 11.5 & 12.55 & 11.50 & 13.90 & 15.20 & 18.90 & 11.50 & 16.40 & 17.20 & 19.50 \\
\hline & $\mathrm{EC}$ & 1200 & 700 & 1200 & 600 & 700 & 700 & 800 & 700 & 800 & 830 & 700 & 670 \\
\hline DW16 & DTWL & 10.18 & 4.00 & 5.94 & 7.89 & 4.69 & 5.39 & 5.59 & 7.29 & 5.39 & 4.59 & 6.10 & Dry \\
\hline & $\mathrm{EC}$ & 800 & 1400 & 800 & 1600 & 1400 & 1200 & 1200 & 1500 & 1700 & 1120 & 1100 & 1072 \\
\hline DW17 & DTWL & 10.62 & 6.45 & 8.00 & 9.90 & 8.70 & 8.75 & 10.20 & 11.30 & 9.35 & 7.20 & 9.35 & 10.20 \\
\hline & $\mathrm{EC}$ & 700 & 1100 & 700 & 1200 & 1300 & 1200 & 1200 & 800 & 1300 & 1360 & NA & NA \\
\hline DW18 & DTWL & 13.30 & 9.00 & 12.00 & 11.60 & 9.75 & 11.20 & 16.90 & 14.85 & 12.85 & 10.42 & 10.85 & 12.90 \\
\hline & $\mathrm{EC}$ & 500 & 800 & 500 & 800 & 800 & 800 & 800 & 700 & 700 & 850 & 800 & 830 \\
\hline DW19 & DTWL & Dry & Dry & 10.75 & 11.60 & 10.90 & 12.45 & 12.30 & 13.10 & 12.75 & 12.80 & 12.90 & 13.10 \\
\hline & $\mathrm{EC}$ & NA & NA & NA & 1200 & 1100 & 1600 & 1000 & 1000 & 800 & 1030 & 1000 & 1100 \\
\hline DW20 & DTWL & 17.06 & 9.75 & 13.00 & 16.20 & 12.20 & 16.20 & Dry & 17.50 & 15.15 & 11.40 & 12.65 & 17.85 \\
\hline & $\mathrm{EC}$ & 600 & 1000 & 600 & 900 & 900 & 900 & NA & 1100 & 1000 & 910 & 950 & 1030 \\
\hline DW21 & DTWL & Dry & Dry & 21.37 & 21.55 & 19.30 & 20.40 & 21.70 & 23.00 & 24.85 & 25.10 & 25.25 & 26.00 \\
\hline & $\mathrm{EC}$ & NA & NA & NA & 800 & 800 & 800 & 900 & 800 & 900 & NA & 800 & 830 \\
\hline DW22 & DTWL & Dry & Dry & 12.40 & 11.50 & 10.80 & 15.50 & 16.20 & 15.70 & 13.05 & 11.50 & 12.70 & 15.80 \\
\hline & $\mathrm{EC}$ & NA & NA & NA & 700 & 700 & 600 & 600 & 600 & 700 & 700 & 700 & 740 \\
\hline DW23 & DTWL & Dry & Dry & 4.00 & Dry & Dry & 6.70 & Dry & Dry & Dry & Dry & Dry & Dry \\
\hline & $\mathrm{EC}$ & NA & NA & NA & NA & NA & 600 & NA & NA & NA & NA & NA & NA \\
\hline DW24 & DTWL & 3.75 & 3.02 & 4.50 & 4.30 & 3.10 & 3.60 & 4.15 & 5.05 & 4.25 & 3.95 & 4.15 & 4.40 \\
\hline & $\mathrm{EC}$ & 1600 & 1900 & 1600 & 1000 & 1600 & 1200 & 700 & 1100 & 1400 & 1500 & 1400 & 1350 \\
\hline DW25 & DTWL & 17.20 & 9.50 & 14.30 & 16.75 & 15.40 & 18.30 & 20.00 & 18.65 & 18.85 & 16.60 & 17.15 & 18.50 \\
\hline & $\mathrm{EC}$ & 1600 & 800 & 1600 & 1400 & 1000 & 1400 & 1700 & 1600 & 1300 & 1200 & 1300 & 1730 \\
\hline DW26 & DTWL & 9.90 & 9.40 & 9.75 & 9.90 & 9.45 & 9.60 & 10.00 & 11.40 & 10.25 & 9.50 & 10.15 & 10.85 \\
\hline & $\mathrm{EC}$ & 700 & 1100 & 700 & 1200 & 800 & 700 & 1000 & 800 & 900 & 680 & 700 & 850 \\
\hline DW27 & DTWL & Dry & NA & 22.45 & 22.40 & 21.10 & 23.75 & 23.80 & 24.50 & 23.50 & 23.00 & 23.15 & 23.90 \\
\hline & $\mathrm{EC}$ & NA & NA & NA & 1000 & 900 & 1000 & 1000 & 1000 & 1100 & 1200 & 900 & 1060 \\
\hline
\end{tabular}


Table 2. (Continued.)

\begin{tabular}{|c|c|c|c|c|c|c|c|c|c|c|c|c|c|}
\hline $\begin{array}{l}\text { Dugwell } \\
\text { no. }\end{array}$ & Parameters & $\begin{array}{l}\text { May } \\
2007\end{array}$ & $\begin{array}{l}\text { Nov } \\
2007\end{array}$ & $\begin{array}{c}\text { Jan } \\
2008\end{array}$ & $\begin{array}{l}\text { May } \\
2008\end{array}$ & $\begin{array}{l}\text { Aug } \\
2008\end{array}$ & $\begin{array}{l}\text { Nov } \\
2008\end{array}$ & $\begin{array}{c}\text { Jan } \\
2009\end{array}$ & $\begin{array}{l}\text { May } \\
2009\end{array}$ & $\begin{array}{l}\text { Aug } \\
2009\end{array}$ & $\begin{array}{l}\text { Nov } \\
2009\end{array}$ & $\begin{array}{c}\text { Jan } \\
2010\end{array}$ & $\begin{array}{l}\text { May } \\
2010\end{array}$ \\
\hline \multirow[t]{2}{*}{ DW28 } & DTWL & 17.54 & 15.45 & 17.20 & 16.70 & 16.10 & 19.50 & 20.20 & 20.00 & 19.75 & 18.45 & 20.15 & 21.35 \\
\hline & $\mathrm{EC}$ & 600 & 1100 & 600 & 1100 & 1100 & 1100 & 1100 & 1100 & 1200 & 1150 & 1100 & 1080 \\
\hline \multirow[t]{2}{*}{ DW29 } & DTWL & 12.65 & 9.90 & 11.10 & 13.00 & 8.10 & 10.80 & Dry & 12.60 & 10.50 & 8.90 & DRY & 12.45 \\
\hline & $\mathrm{EC}$ & 1000 & 800 & 1000 & 700 & 800 & 700 & NA & 700 & 800 & 800 & 800 & 810 \\
\hline \multirow[t]{2}{*}{ DW30 } & DTWL & 19.85 & 13.20 & 14.30 & 17.25 & 13.80 & 14.50 & 16.40 & 20.50 & 17.80 & 16.80 & 19.20 & 21.80 \\
\hline & $\mathrm{EC}$ & 1100 & 1600 & 1100 & 1200 & 700 & 800 & 1400 & 1200 & 1000 & 1560 & 1100 & 1130 \\
\hline \multirow[t]{2}{*}{ DW31 } & DTWL & 4.70 & 2.55 & 3.05 & 4.05 & 2.95 & 3.50 & 3.70 & 5.55 & 4.80 & 3.40 & 4.10 & 5.40 \\
\hline & $\mathrm{EC}$ & 1500 & 600 & 1500 & 600 & 800 & 600 & 600 & 600 & 1000 & 870 & 700 & 690 \\
\hline \multirow[t]{2}{*}{ DW32 } & DTWL & Dry & Dry & 11.60 & Dry & 11.80 & Dry & Dry & Dry & 14.85 & 12.00 & 12.85 & Dry \\
\hline & $\mathrm{EC}$ & NA & NA & NA & NA & 1600 & NA & NA & NA & 1600 & 1740 & NA & NA \\
\hline \multirow[t]{2}{*}{ DW33 } & DTWL & Dry & Dry & 1.90 & 2.25 & 0.70 & 2.50 & 3.00 & 3.75 & 2.00 & 1.80 & 2.60 & 3.70 \\
\hline & $\mathrm{EC}$ & NA & NA & NA & 500 & NA & 500 & 900 & 500 & NA & 550 & 500 & 470 \\
\hline \multirow[t]{2}{*}{ DW34 } & DTWL & Dry & Dry & 15.70 & 16.80 & 16.65 & 16.70 & 17.85 & 19.80 & 18.20 & 17.45 & 18.70 & 20.30 \\
\hline & $\mathrm{EC}$ & NA & NA & NA & 1200 & 1200 & 1200 & 1200 & 1000 & 1200 & 1300 & 1200 & 1230 \\
\hline
\end{tabular}

totally 34 key dug wells, representing shallow aquifers and covering all the hydrogeological units of WR-2 watershed were selected to study the groundwater regime and its quality, over the area of $632 \mathrm{~km}^{2}$ (figure 2). The selected dug wells include two 'Groundwater Monitoring Wells' DW11 and DW30 of the Central Ground Water Board (CGWB) that are located at Warud and Loni villages, respectively. The representative dug wells were monitored for DTWL and spot/field EC from January 2007 to May 2010 on quarterly basis, i.e., for the months of January, May (pre-monsoon), August (monsoon) and November (post-monsoon). This was carried out to verify the trends of DTWL and EC variation and its impact on groundwater quality. Out of 34 dug wells, 32 were selected for analysis due to continuity and availability of data.

The DTWL and spot/field EC data of CGWB recorded at Warud (DW11) and Loni (DW30) villages, during 1977-2010 (CGWB 2010) was utilised to study the impact of long term over-exploitation of groundwater on its quality along with the data collected from key dug wells, during present study. The well inventory data and hydrogeological details of these dug wells collected during present field investigations are shown in table 1 , whereas the DTWL and EC data are presented in table 2.

Moreover, groundwater sampling from the key dug wells was carried out during pre-monsoon season of 2008 (May 2008) for detailed hydrochemical investigations. Totally 32 groundwater samples were collected from representative dug wells, as two dug wells (DW23 and DW32) were found dry during the sampling period. Physical parameters of water samples like $\mathrm{pH}$ and spot EC were measured in the field, immediately after the sampling, using portable EC meter. All standard precautions, necessary for reliable estimation were observed during field measurement. The accuracy of measurement was \pm 0.1 units. The groundwater samples after collection were subjected to determination of hydrochemical parameters such as total dissolved solids (TDS) and total hardness (TH) along with calcium $(\mathrm{Ca})$, magnesium $(\mathrm{Mg})$, sodium $(\mathrm{Na})$, potassium $(\mathrm{K})$, carbonate $\left(\mathrm{CO}_{3}\right)$, bicarbonate $\left(\mathrm{HCO}_{3}\right)$, chloride $(\mathrm{Cl})$, sulphate $\left(\mathrm{SO}_{4}\right)$, nitrate $\left(\mathrm{NO}_{3}\right)$ and fluoride $(\mathrm{F})$ ions. The sampling, preservation, and analytical techniques used are as per the reputed laboratories for analysis of groundwater samples and American Public Health Association (APHA) manual of 'Standard Methods for Examination of Water and Wastewater' (Handa 1981; NEERI 1986; APHA 1998). The accuracy of chemical data for major ions is estimated from the electro neutrality condition (Rossum 1975; Friedman and Erdmann 1982; Appelo and Postma 1993). The specific analysis for identification of pesticides and fertilizers was not carried out; hence, the risks associated with it to human being are not included.

Spot/field EC is selected for assessment of groundwater quality as it represents total ionic content in water. It indicates the extent of mineralisation in groundwater and generally increases with contamination, flow, and residence time of water in the aquifers. It is one of the important parameters that reflect even minor changes in the quality of groundwater from shallow aquifers (Deutsch 1997; Madnure et al. 2007).

\section{Hydrogeology}

About $91.27 \%\left(577 \mathrm{~km}^{2}\right)$ area of the WR-2 watershed is covered by Deccan trap basaltic lava flows and the rest of the area, about $8.72 \%\left(55 \mathrm{~km}^{2}\right)$, by Wardha river alluvium. The basaltic lava flows 
have two hydrogeological units, viz., a vesicular unit confined to the upper part and a massive unit restricted to the lower part of the flow. The vesicular units possess interconnected vesicles that provide pore spaces for storage and movement of groundwater and acts as a good aquifer, particularly at shallow depth. Whereas, the lower massive unit is hard, compact, and has less primary porosity and permeability. Groundwater occurs under phreatic conditions in the exposed vesicular lava flows and in semi-confined state in the jointed and fractured portions of massive subsurface flows. The alluvial deposits are unevenly distributed and restricted to the banks of Wardha river. The coarser detrital material occurring as lenses forms good water bearing strata in alluvium. Whereas, finer clayey and silty material has poor permeability and does not permit movement of groundwater. The groundwater occurs under phreatic conditions in sandy layers.

The availability of groundwater is extremely uneven, both spatially and temporally. The uneven distribution of groundwater can be attributed to heterogeneous lithology of the aquifers and uneven distribution of rainfall (CGWB and GSDA 2005). The shallow groundwater, tapped by large diameter

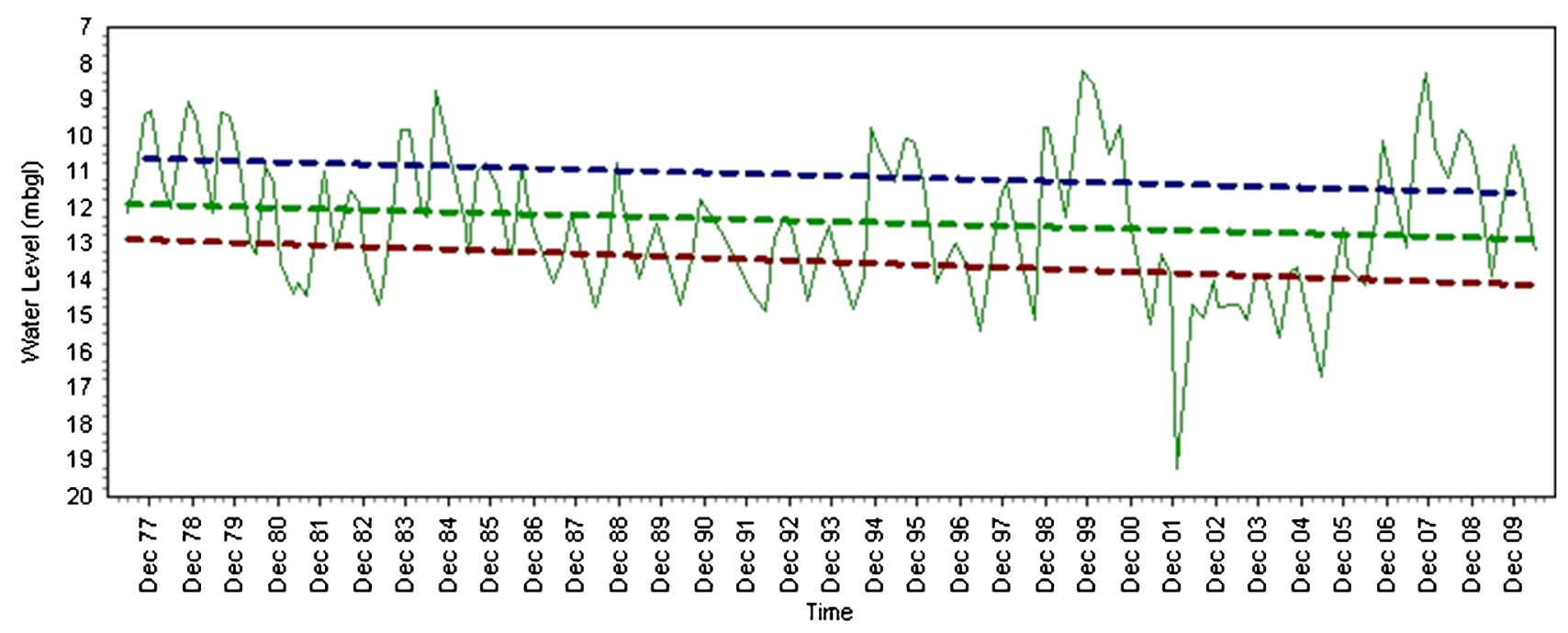

\begin{tabular}{|c|c|}
\hline$\sqrt{\nabla}-$ AlM MrLvl & 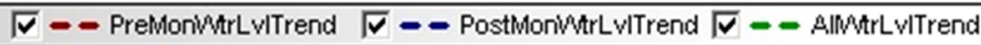 \\
\hline & $\begin{array}{l}\text { Prelhonsoon Water Level Trend: } Y=-0.003178 X+12.883213 \\
\text { Post Monsoon Wibter Level Thend: } Y=-0.002535 X+10.608781 \\
\text { All Wigter Level Trend: } Y=-0.002507 X+11.878383\end{array}$ \\
\hline
\end{tabular}

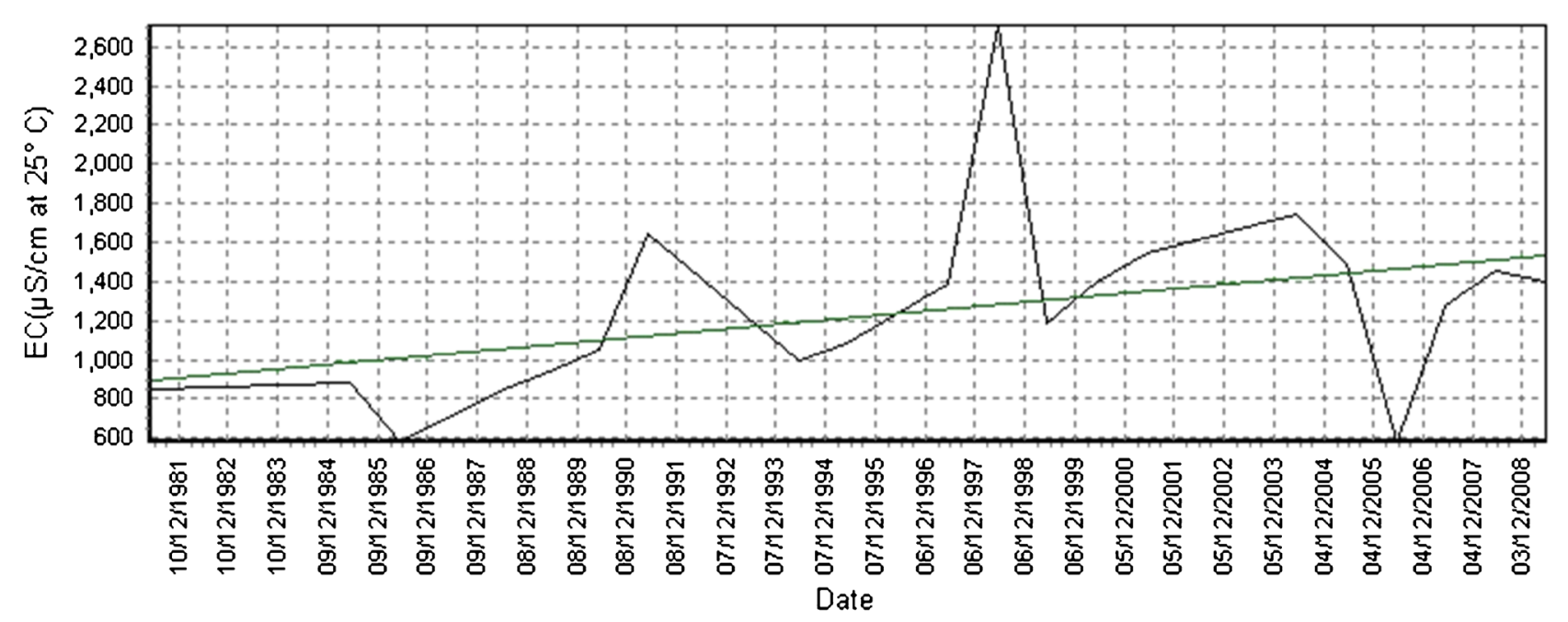

(b)

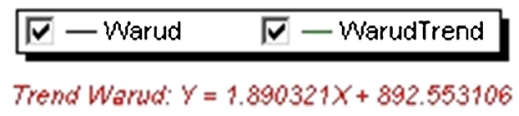

Figure 3. (a). DTWL vs. time plot of groundwater monitoring dug well of Warud (DW11) during 1977-2009. (b) Long term EC vs. time plot of groundwater monitoring dug well of Warud (DW11) during 1981-2008. 
shallow dug wells, is the most important source of water, especially in the large rural tracts of the study area. The groundwater movement in the study area is mainly controlled by topography, drainage pattern, and structural controls over the area. The groundwater flow direction is towards the south which ultimately converges into the Wardha river.

In the WR-2 watershed, the depth of dug wells varies from 4.85 to $27.80 \mathrm{~m} \mathrm{bgl}$ (meters below ground level), whereas their diameter varies from 1.10 to $4.80 \mathrm{~m}$ (table 1 ). However, at places around Jarud, Davergaon, Mangruli, Wadala, Gadegaon, Loni and Haturna villages, the dug well depth varies from $20 \mathrm{~m}$ bgl to maximum $30 \mathrm{~m} \mathrm{bgl,} \mathrm{pierc-}$ ing the entire unconfined phreatic aquifer. This may be due to deeper DTWL and prevailing local hydrogeological conditions. The depth of weathering in WR-2 watershed was estimated from the depth of curbing in the existing dug wells, well sections of open wells, and borehole logs. The depth of weathering ranges from 1.30 to $14.30 \mathrm{~m} \mathrm{bgl}$ (table 1) and in general, increases from north to south, i.e., in the direction of general ground slope. In the central part of WR-2 watershed around Jarud-Warud villages, the depth of weathering is relatively high as compared to the surrounding areas. Dug well density and agricultural activity

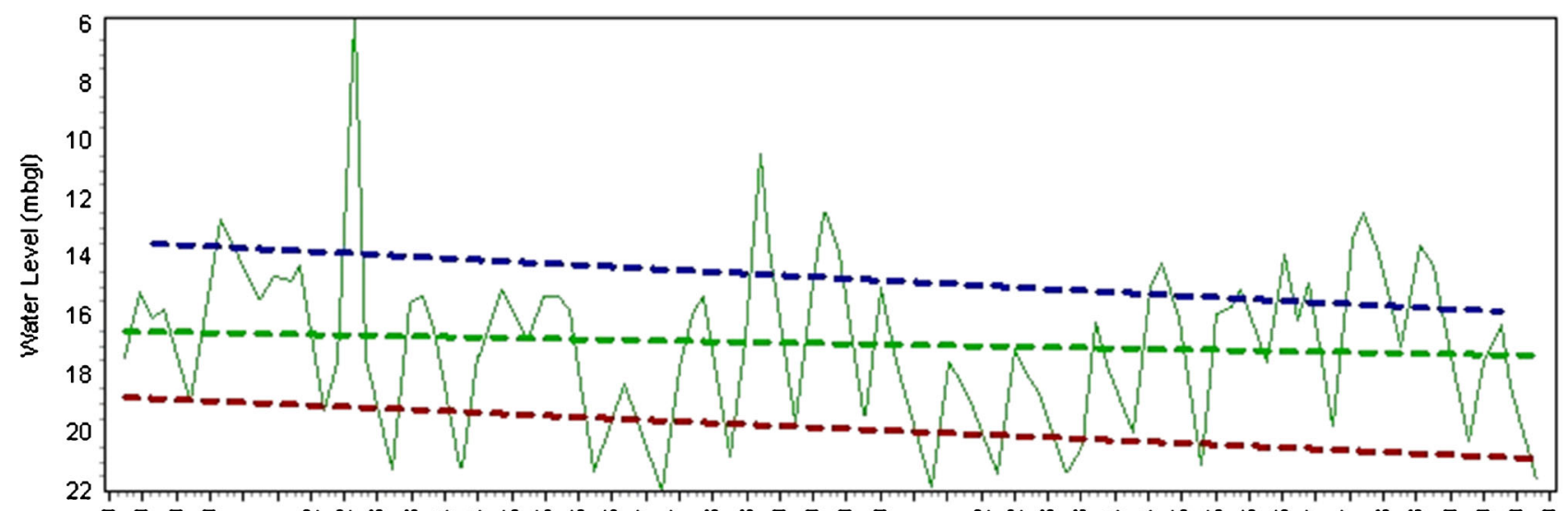

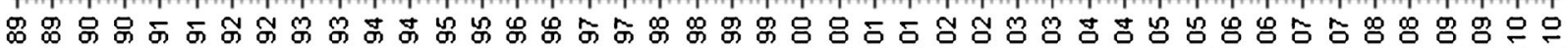

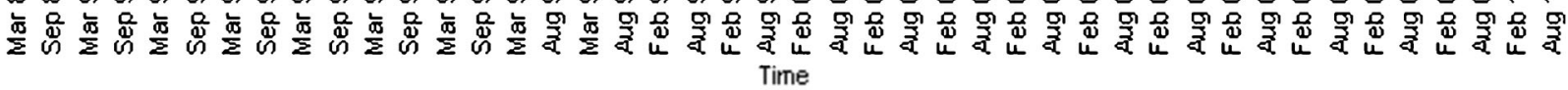

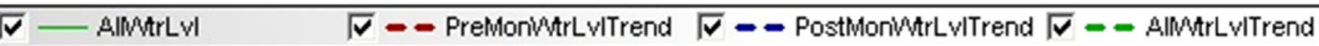

Prelhonsoon Water Level Trend: $Y=-0.008163 X+18.766060$ Post Monsoon Water Le vel Trend: $Y=-0.009646 X+13.517280$

(a) An hater Level Trend: $Y=-0.003283 X+16.522820$

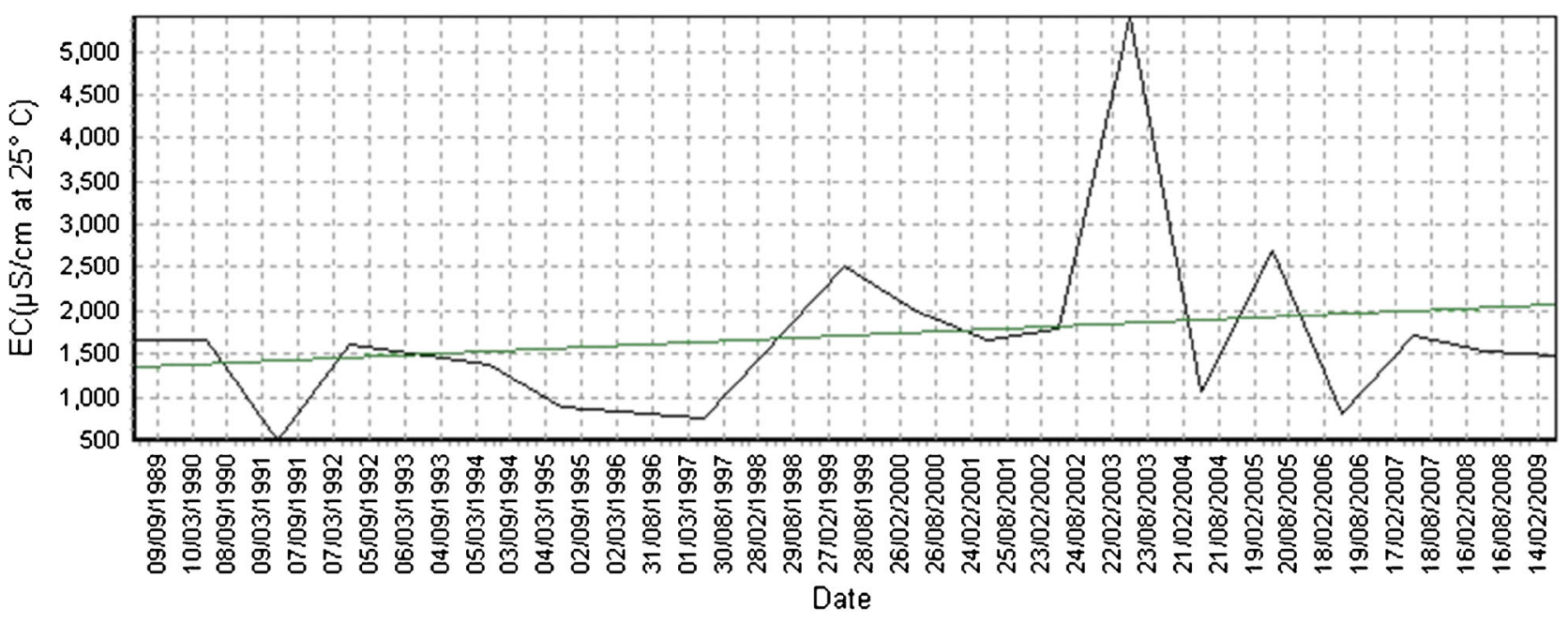

(b)

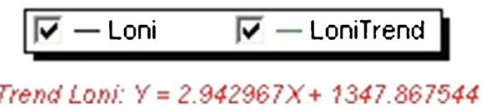

Figure 4. (a). DTWL vs. time plot of groundwater monitoring dug well of Loni (DW30) during 1989-2010. (b) Long term EC vs. time plot of groundwater monitoring dug well of Loni (DW30) during 1989-2009. 
are also relatively more in and around JarudWarud areas. However, along the northern bank of Wardha river the thickness of weathered and porous zone in dug well sections is high as these wells are mostly hosted in alluvium (figure 2). The depth of weathering in Deccan Trap basalt and alluvium area is controlled by the nature of lithology, intensity of fracturing, and joints, etc.

\subsection{Trends of water level and water quality}

The long term depth to water level (DTWL) trend recorded at the 'Groundwater Monitoring Wells' of CGWB at Warud (DW11) during 19772009, and Loni (DW30) during 1989-2010 shows a decline of 0.03 and $0.04 \mathrm{~m}$ per year, respectively. The corresponding trend of EC shows rise of 1.90 and $2.94 \mu \mathrm{S} / \mathrm{cm}$ per year, respectively in these dug wells, over the same period (CGWB 2010) (figures 3a, 3b, 4a and 4b).

The short term (2007-2010) DTWL and EC trends, recorded in the dug wells of the study area, reveal that during pre-monsoon seasons of 20072010, DTWL varied from 2.25 to $26 \mathrm{~m} \mathrm{bgl}$ and corresponding spot/field EC ranged from 300 to $1730 \mu \mathrm{S} / \mathrm{cm}$, respectively. Whereas, during postmonsoon seasons of 2007-2009, the DTWL varied from 1.8 to $25.1 \mathrm{~m} \mathrm{bgl}$ and spot/field EC varied from 400 to $1900 \mu \mathrm{S} / \mathrm{cm}$, respectively (table 2 ).

During monsoon season (August) of 20082009, the DTWL varied from 0.7 to $24.85 \mathrm{~m} \mathrm{bgl}$ and corresponding spot/field EC ranged from 400 to $1700 \mu \mathrm{S} / \mathrm{cm}$, respectively. Whereas, during January months of 2008-2010, the DTWL varied from 1.9 to $25.25 \mathrm{~m} \mathrm{bgl}$ and corresponding EC ranged from 300 to $1700 \mu \mathrm{S} / \mathrm{cm}$, respectively, in the dug wells of the study area (table 2 ).

The data thus collected indicate that irrespective of the sampling seasons DTWL show declining trend and EC show rising trend in the dug wells of the study area and about 18 dug wells out of the total (i.e., $56 \%$ dug wells) show positive correlation between decline of DTWL and rise in EC values (tables 2 and 3). The declining trend of DTWL ranged from 0.03 to $0.67 \mathrm{~m}$ per year, whereas the corresponding rising spot/field EC trend ranged from 0.52 to $46.91 \mu \mathrm{S} / \mathrm{cm}$ per year, respectively, during 2007 to 2010 (table 3). The graphical presentation of correlation between DTWL, EC and time for the representative dug wells of DW2, DW6, DW11, DW12, DW13, DW20, DW21, DW22, DW25, DW27, DW28, DW30 and DW34 are shown in figure $5(\mathrm{a}$ and $\mathrm{b})$. The DTWL and EC variation trend maps for the period of 2007-2010 are presented in figures 6 and 7. The variation in long term and short term water level trends may be due to variation in natural
Table 3. Correlation between declining DTWL and rising spot/field EC trends during 2007-2010 in the dug wells of WR-2 watershed.

\begin{tabular}{|c|c|c|c|}
\hline $\begin{array}{l}\text { Dugwell } \\
\text { no. }\end{array}$ & $\begin{array}{l}\text { Trend of water } \\
\text { level }(\mathrm{m} / \text { year })^{*}\end{array}$ & $\begin{array}{l}\text { Trend of spot EC } \\
(\mu \mathrm{S} / \mathrm{cm} / \text { year })^{*}\end{array}$ & Correlation \\
\hline DW1 & -0.1276 & 11.25 & -0.81 \\
\hline DW2 & 0.1558 & 35.14 & 0.11 \\
\hline DW3 & -0.2367 & 26.89 & -0.45 \\
\hline DW4 & 0.2221 & -18.33 & -0.49 \\
\hline DW5 & -0.1083 & 26.39 & -0.41 \\
\hline DW6 & 0.3296 & 22.97 & 0.05 \\
\hline DW7 & 0.4033 & 1.82 & 0.01 \\
\hline DW8 & 0.2072 & -12.97 & -0.58 \\
\hline DW9 & 0.3174 & 7.56 & -0.07 \\
\hline DW10 & 0.0291 & 27.33 & -0.65 \\
\hline DW11 & 0.202 & 11.01 & 0.64 \\
\hline DW12 & 0.4306 & 10.97 & -0.17 \\
\hline DW13 & 0.4852 & 9.00 & -0.49 \\
\hline DW14 & 0.0813 & -35.56 & 0.00 \\
\hline DW15 & 0.5622 & -25.59 & -0.06 \\
\hline DW16 & -0.1817 & 11.65 & -0.27 \\
\hline DW17 & 0.0783 & 46.91 & -0.34 \\
\hline DW18 & 0.0994 & 18.46 & -0.24 \\
\hline DW19 & 0.2512 & -34.00 & -0.23 \\
\hline DW20 & 0.1138 & 26.45 & 0.04 \\
\hline DW21 & 0.6741 & 3.20 & 0.26 \\
\hline DW22 & 0.21 & 7.67 & -0.59 \\
\hline DW24 & 0.0686 & -27.80 & -0.53 \\
\hline DW25 & 0.4238 & 16.54 & 0.71 \\
\hline DW26 & 0.082 & -11.50 & -0.03 \\
\hline DW27 & 0.1682 & 12.33 & 0.32 \\
\hline DW28 & 0.4217 & 33.67 & 0.29 \\
\hline DW29 & -0.0271 & -11.14 & 0.01 \\
\hline DW30 & 0.4115 & 0.52 & 0.03 \\
\hline DW31 & 0.1253 & -38.53 & -0.02 \\
\hline DW33 & 0.1418 & -10.92 & 0.00 \\
\hline DW34 & 0.3948 & 5.33 & -0.40 \\
\hline
\end{tabular}

*Positive values indicate declining DTWL and rising EC trends.

recharge, rainfall, and excessive withdrawal of groundwater.

Moreover, the long term (1977-2010) and short term (2007-2010) record of the DTWL and spot/field EC in the dug wells of the study area indicate that the decline in DTWL is directly proportional to the rising EC values. The declining DTWL trend indicates progressive scarcity of groundwater, whereas rising EC values indicate deterioration of the groundwater quality in the dug wells of phreatic shallow aquifers of WR-2 watershed. This is reflected in terms of higher concentration of $\mathrm{Ca}, \mathrm{Mg}$, TDS, and $\mathrm{TH}$ in the groundwater of the study area. Moreover, the DTWL data show that the areas in the central and southern parts of WR-2 watershed have deeper DTWL and are more susceptible to groundwater exploitation. 


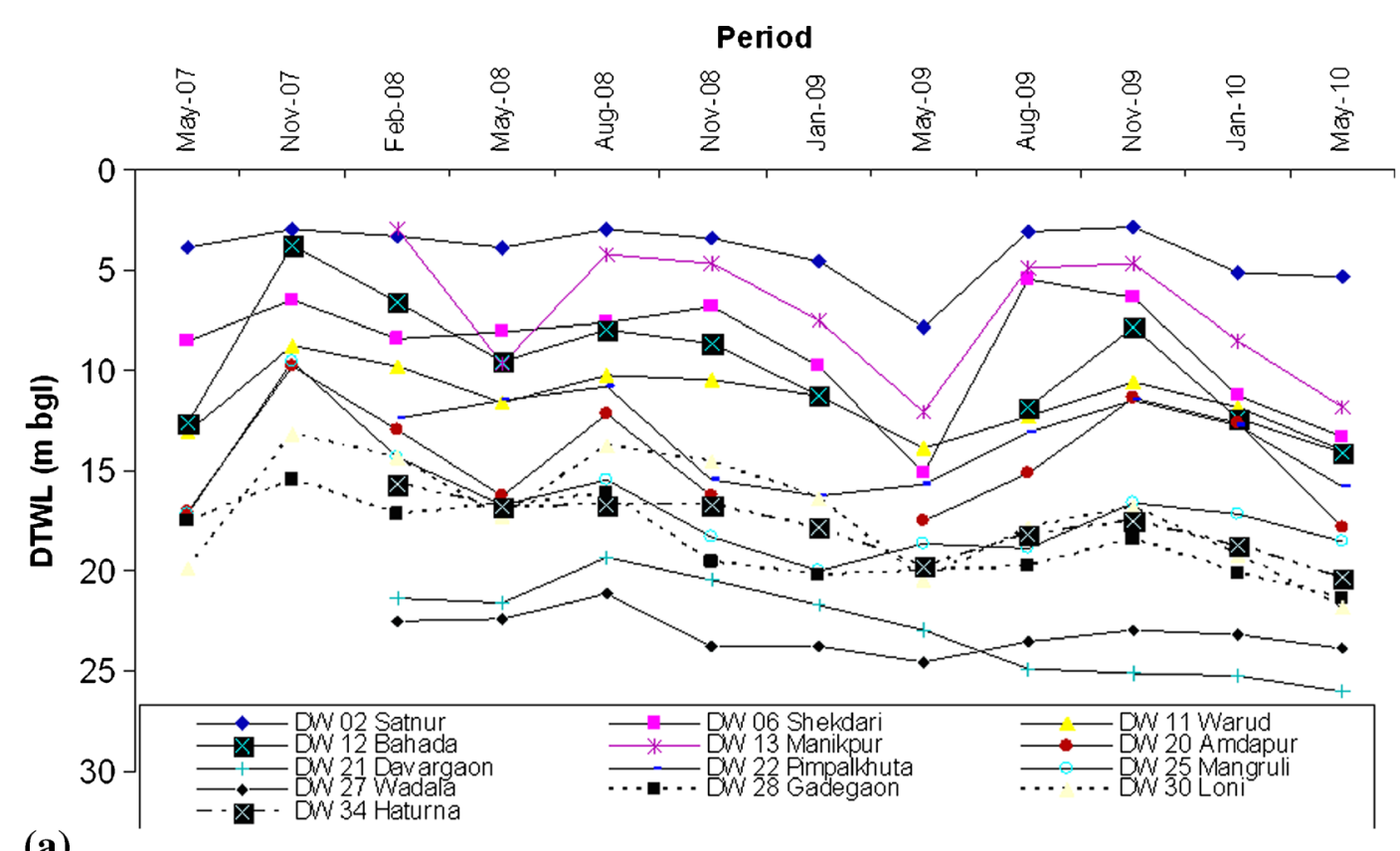

(a)

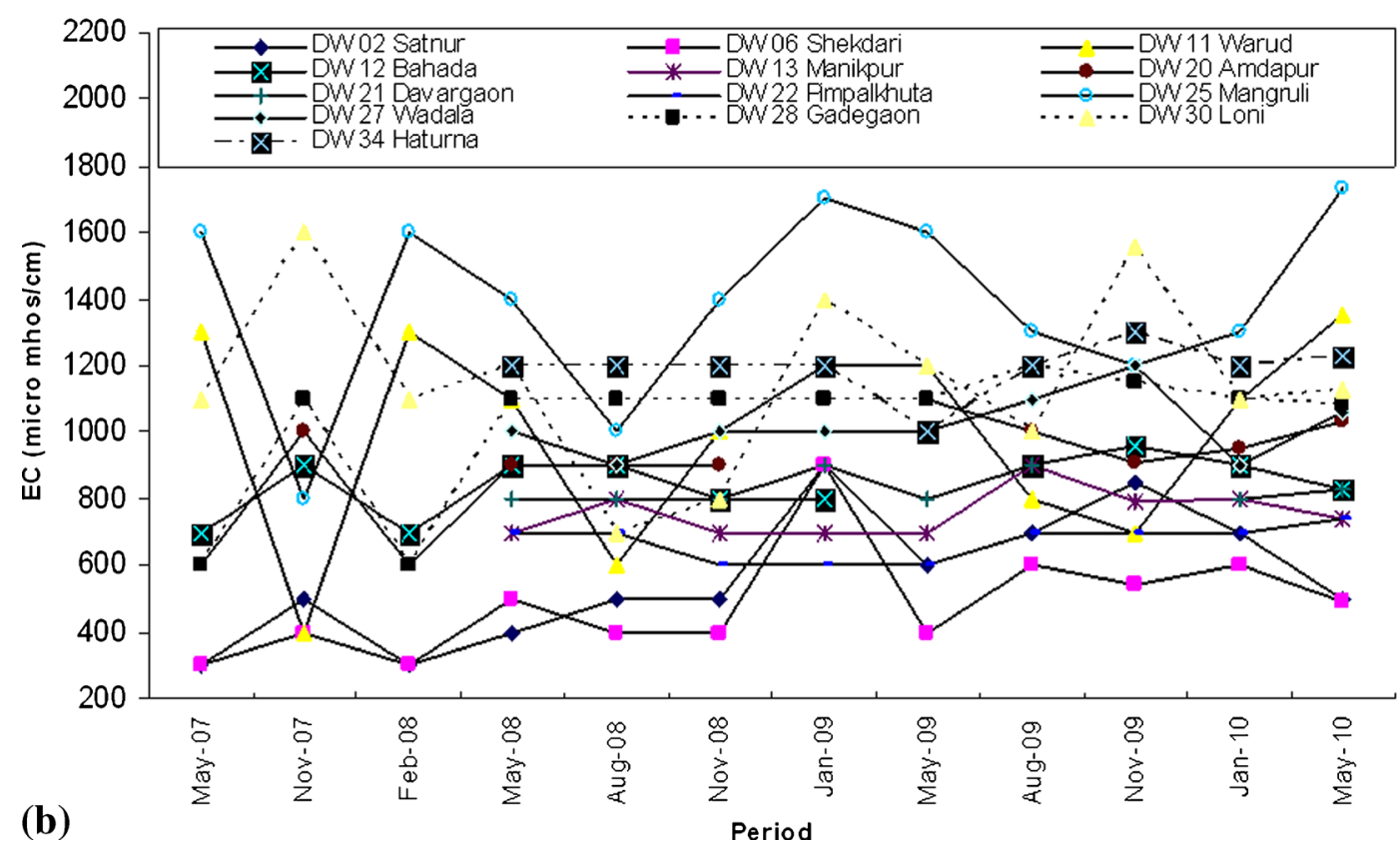

Figure 5. (a). DTWL vs. time plot of selected dug wells of WR-2 watershed during 2007-2010. (b) EC vs. time plot of selected dug wells of WR-2 watershed during 2007-2010.

These regions have more groundwater overdraft than the natural recharge and show excessive groundwater exploitation as compared to the rest of the areas.

\section{Hydrochemistry}

Hydrochemical studies were carried out during premonsoon season of 2008, in order to verify the DTWL and EC trends related to declining water level and deteriorating groundwater quality. The parameter-wise results of detailed hydrochemical investigations of groundwater samples are summarized in table 4. The EC values in this case are determined in laboratory and found almost similar to the spot/field EC values for May 2008, except minor variations at some places.

Analytical results show that groundwater of the study area is mildly alkaline in nature, with average $\mathrm{pH}$ of 7.8 , and moderately mineralized as indicated by the EC and TDS values that range from 580 to $1920 \mu \mathrm{S} / \mathrm{cm}$ and from 292 to $992 \mathrm{mg} / \mathrm{l}$, respectively. The degree of mineralization was found low 


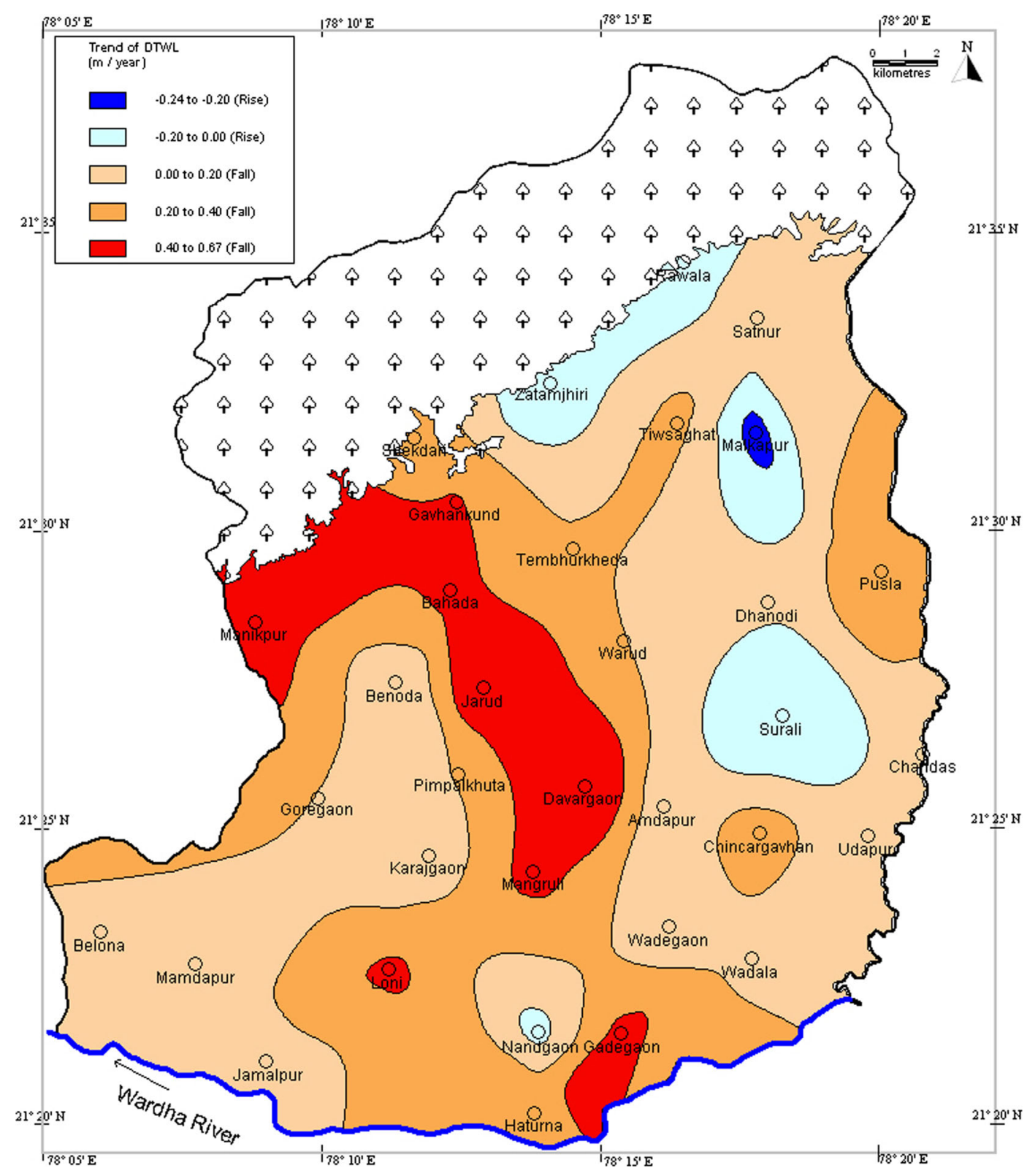

Figure 6. DTWL trend map of the dug wells of WR-2 watershed during 2007-2010.

in the groundwater sample from dug well DW2, while it was highest in groundwater from DW16 (table 4).

Total alkalinity of groundwater ranges from 200 to $575 \mathrm{mg} / \mathrm{l}$ as $\mathrm{CaCO}_{3}$, with average value more than $336 \mathrm{mg} / \mathrm{l}$ (table 4). This may severely affect the use of water for different purposes. The maximum $\mathrm{pH}$ of groundwater is 8.0, which indicates bicarbonate as the dominant species in groundwater and mainly contributing towards its alkalinity (Tiwari et al. 2007, 2008).

Total hardness of groundwater ranges from 200 to $690 \mathrm{mg} / \mathrm{l}$, with average value of $386 \mathrm{mg} / \mathrm{l}$. This indicates that groundwater of the study area is hard in nature and hardness is mainly due to the bicarbonate salts of $\mathrm{Ca}$ and $\mathrm{Mg}$. The concentrations of $\mathrm{Cl}$ and $\mathrm{SO}_{4}$ in groundwater are less as compared to $\mathrm{HCO}_{3}$ ions, indicating that the water has more temporary hardness than permanent and can be removed by boiling the water. The average concentration of fluoride, which exists as minor ion in the groundwater of the study area, is less than $0.5 \mathrm{mg} / \mathrm{l}$ (table 4) (Seaber 1962; Tiwari et al. 2007, 2008).

\subsection{Schoeller's classification}

Schoeller $(1955,1967)$ has given the classification scheme for water types based on $\mathrm{Cl}, \mathrm{SO}_{4}$, and $\mathrm{HCO}_{3}+\mathrm{CO}_{3}$ concentrations. As per this classification, chloride concentration below $15 \mathrm{meq} / \mathrm{l}$ is termed as normal chloride water. Similarly, water with sulphate content of $<6 \mathrm{meq} / \mathrm{l}$ is termed 


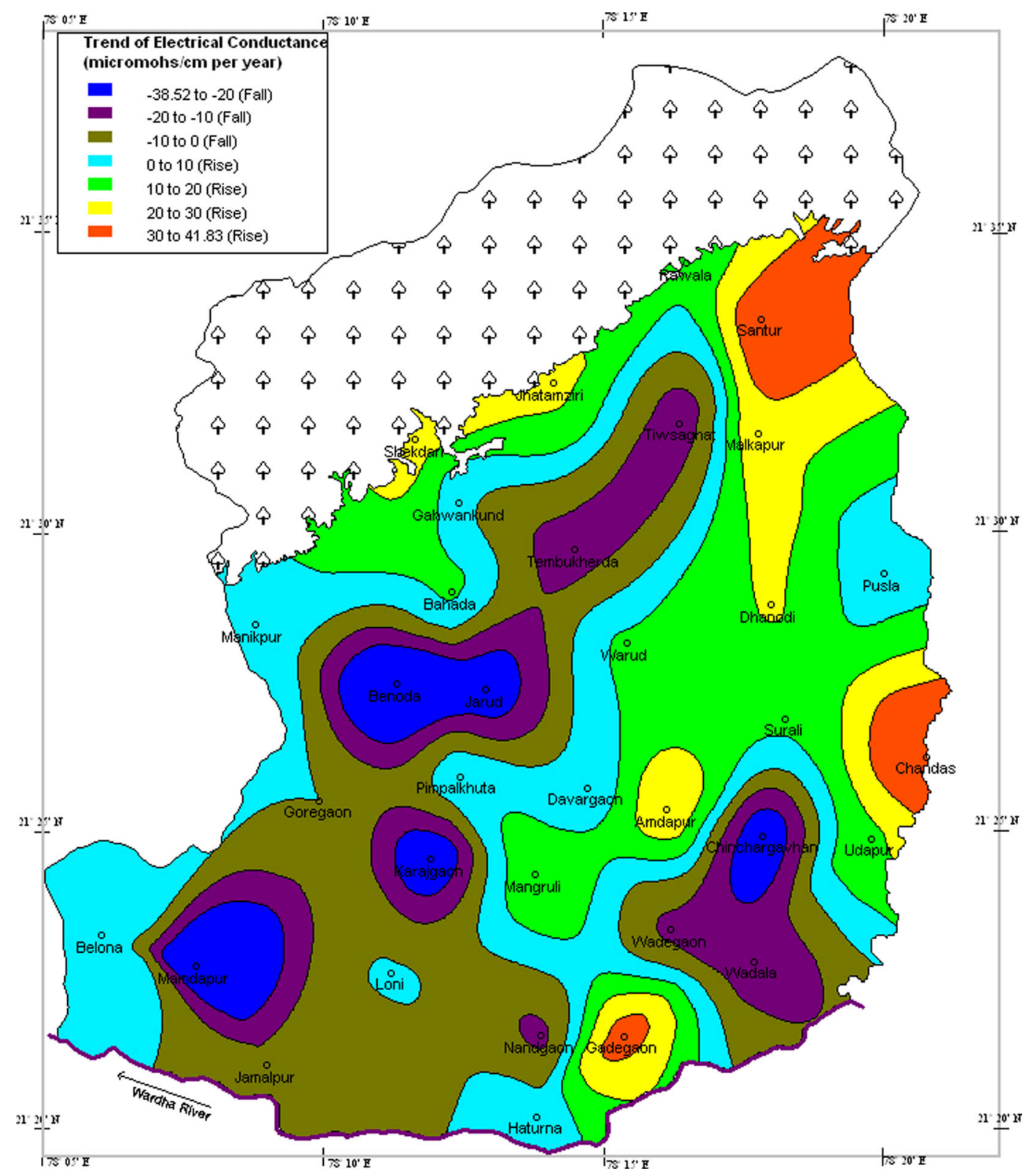

Figure 7. EC trend map of the dug wells of WR-2 watershed during 2007-2010.

as normal sulphate water (Schoeller 1955, 1967; Freeze and Cherry 1979; Hem 1985).

During pre-monsoon season of 2008, chloride concentration in groundwater samples of the study area is $<15 \mathrm{meq} / \mathrm{l}$, indicating normal chloride water. Differentiation of $\mathrm{SO}_{4}$ concentration indicates the groundwater as normal sulphate water, as $\mathrm{SO}_{4}<6 \mathrm{meq} / \mathrm{l}$ and differentiation of $\mathrm{HCO}_{3}+\mathrm{CO}_{3}$ concentration indicates it as sulphate carbonate waters, as $\mathrm{HCO}_{3}+\mathrm{CO}_{3}>7$ meq/l (Schoeller 1955, 1967). The concentrations of major ions expressed in meq/l are graphically presented using Schoeller's diagram (figure 8). This shows that concentration of $\mathrm{Ca}$ exceeds that of $\mathrm{Mg}$ followed by $\mathrm{Na}$ amongst the cations, while $\mathrm{HCO}_{3}$ ion has higher concentration than $\mathrm{Cl}$ followed by $\mathrm{NO}_{3}$ and $\mathrm{SO}_{4}$ in the groundwater samples of the study area.

\subsection{Piper's diagram}

The trilinear diagram of Piper (1944) is very useful in bringing out chemical relationships among groundwaters in more definite terms (Walton 1970). The geochemical classification of groundwater of the study area was carried out by subjecting the samples to graphical treatment and plotting them on Piper's trilinear diagram (Piper 1944, 1953) (figure 9). Piper's diagram indicates that groundwater of the study area is predominately of $\mathrm{Ca}-\mathrm{HCO}_{3}$ type and represents characteristics of 
Table 4. Chemical analysis of groundwater samples from dug wells of WR-2 watershed for pre-monsoon season of 2008.

\begin{tabular}{|c|c|c|c|c|c|c|c|c|c|c|c|c|c|c|}
\hline \multirow{2}{*}{$\begin{array}{l}\text { Dugwell } \\
\text { no. }\end{array}$} & \multirow[b]{2}{*}{$\mathrm{pH}$} & \multirow{2}{*}{$\begin{array}{c}\mathrm{EC} \\
(\mu \mathrm{S} / \mathrm{cm})\end{array}$} & TDS & $\mathrm{TH}$ & TA & $\mathrm{Ca}$ & $\mathrm{Mg}$ & $\mathrm{Na}$ & $\mathrm{K}$ & $\mathrm{HCO}_{3}$ & $\mathrm{Cl}$ & $\mathrm{SO}_{4}$ & $\mathrm{NO}_{3}$ & $\mathrm{~F}$ \\
\hline & & & \multicolumn{12}{|c|}{$(\mathrm{mg} / \mathrm{l})$} \\
\hline DW1 & 7.9 & 800 & 402 & 360 & 315 & 70 & 45 & 16.3 & 0.2 & 384 & 21 & 30 & 27 & 0.62 \\
\hline DW2 & 7.9 & 580 & 292 & 245 & 260 & 64 & 21 & 19.3 & 0.3 & 317 & 11 & 14 & 2.8 & 0.79 \\
\hline DW3 & 7.9 & 680 & 374 & 295 & 230 & 86 & 19 & 17.2 & 0.8 & 281 & 32 & 8 & 70 & 0.35 \\
\hline DW4 & 7.4 & 1390 & 850 & 625 & 230 & 156 & 57 & 29 & 0.9 & 281 & 113 & 108 & 246 & 0.35 \\
\hline DW5 & 7.9 & 690 & 341 & 300 & 320 & 72 & 29 & 19.7 & 1 & 390 & 14 & 5.8 & 3.9 & 0.51 \\
\hline DW6 & 7.6 & 590 & 303 & 250 & 245 & 56 & 27 & 19.7 & 0.6 & 299 & 11 & 16 & 23 & 0.58 \\
\hline DW7 & 7.5 & 630 & 332 & 265 & 235 & 64 & 26 & 21 & 1.4 & 287 & 32 & 21 & 23 & 0.52 \\
\hline DW8 & 7.6 & 1610 & 928 & 625 & 330 & 124 & 77 & 78 & 0.6 & 403 & 184 & 42 & 220 & 0.56 \\
\hline DW9 & 7.6 & 640 & 356 & 235 & 200 & 64 & 18 & 37 & 0.4 & 244 & 39 & 32 & 43 & 0.70 \\
\hline DW10 & 7.7 & 840 & 460 & 370 & 260 & 90 & 35 & 22 & 0.9 & 317 & 64 & 12 & 78 & 0.26 \\
\hline DW11 & 7.9 & 1350 & 740 & 535 & 395 & 114 & 61 & 61 & 1 & 482 & 106 & 42 & 113 & 0.39 \\
\hline DW12 & 7.5 & 950 & 524 & 420 & 255 & 90 & 47 & 24 & 0.2 & 311 & 74 & 39 & 93 & 0.31 \\
\hline DW13 & 7.9 & 920 & 490 & 390 & 325 & 78 & 47 & 28 & 4.5 & 397 & 43 & 31 & 59 & 0.34 \\
\hline DW14 & 7.5 & 680 & 362 & 305 & 220 & 80 & 26 & 14.7 & 0.4 & 268 & 57 & 20 & 30 & 0.12 \\
\hline DW15 & 7.6 & 770 & 412 & 325 & 265 & 72 & 35 & 26 & 0.3 & 323 & 32 & 29 & 56 & 0.26 \\
\hline DW16 & 8.0 & 1920 & 992 & 690 & 575 & 160 & 70 & 112 & 9.1 & 702 & 262 & 5.2 & 22 & 0.37 \\
\hline DW17 & 7.6 & 1530 & 823 & 375 & 570 & 92 & 35 & 161 & 9.6 & 696 & 121 & 18 & 38 & 0.43 \\
\hline DW18 & 7.8 & 970 & 490 & 330 & 420 & 40 & 56 & 69 & 1.2 & 512 & 21 & 14 & 32 & 0.18 \\
\hline DW19 & 7.8 & 1210 & 652 & 450 & 430 & 54 & 77 & 67 & 0.7 & 525 & 46 & 10 & 135 & 0.29 \\
\hline DW20 & 7.7 & 1120 & 602 & 390 & 410 & 56 & 61 & 69 & 0.6 & 500 & 53 & 13 & 98 & 0.41 \\
\hline DW21 & 7.9 & 1010 & 515 & 395 & 410 & 54 & 63 & 46 & 0.3 & 500 & 35 & 11 & 55 & 0.31 \\
\hline DW22 & 7.8 & 800 & 418 & 265 & 340 & 46 & 36 & 56 & 1.1 & 415 & 21 & 4 & 45 & 0.50 \\
\hline DW23 & & & & & & & & & & & & & & \\
\hline DW24 & 8.0 & 1180 & 627 & 410 & 405 & 80 & 51 & 80 & 0.7 & 494 & 85 & 15 & 68 & 0.34 \\
\hline DW25 & 7.6 & 1470 & 800 & 540 & 340 & 76 & 85 & 88 & 0.3 & 415 & 199 & 21 & 122 & 0.28 \\
\hline DW26 & 7.8 & 1440 & 774 & 605 & 240 & 168 & 45 & 47 & 4.4 & 293 & 291 & 58 & 14 & 0.45 \\
\hline DW27 & 7.8 & 1120 & 602 & 240 & 430 & 46 & 30 & 142 & 1.2 & 525 & 57 & 8 & 56 & 0.23 \\
\hline DW28 & 7.7 & 1190 & 630 & 395 & 400 & 54 & 63 & 84 & 0.9 & 488 & 89 & 12 & 82 & 0.09 \\
\hline DW29 & 7.7 & 700 & 378 & 290 & 245 & 60 & 34 & 23 & 0.9 & 299 & 32 & 9 & 70 & 0.57 \\
\hline DW30 & 7.9 & 1400 & 778 & 545 & 350 & 88 & 79 & 67 & 2.1 & 427 & 128 & 44 & 156 & 0.48 \\
\hline DW31 & 7.8 & 650 & 352 & 285 & 235 & 60 & 33 & 18.5 & 0.2 & 287 & 25 & 8 & 64 & 0.72 \\
\hline DW32 & & & & & & & & & & & & & & \\
\hline DW33 & 7.8 & 670 & 337 & 200 & 315 & 36 & 27 & 54 & 6.6 & 384 & 14 & 5.2 & 1.2 & 0.90 \\
\hline DW34 & 7.9 & 1390 & 720 & 410 & 550 & 46 & 72 & 126 & 0.3 & 671 & 64 & 18 & 58 & 0.25 \\
\hline Minimum & 7.4 & 580 & 292 & 200 & 200 & 36 & 18 & 14.7 & 0.2 & 244 & 11 & 4 & 1.2 & 0.09 \\
\hline Maximum & 8.0 & 1920 & 992 & 690 & 575 & 168 & 85 & 161 & 9.6 & 702 & 291 & 108 & 246 & 0.90 \\
\hline Average & 7.8 & 1028 & 552 & 386 & 336 & 78 & 46 & 54 & 1.7 & 410 & 74 & 23 & 69 & 0.50 \\
\hline
\end{tabular}

groundwater from basaltic aquifers. Few samples fall in the category of mixed type of water. The alkaline earths $(\mathrm{Ca}+\mathrm{Mg})$ exceed alkalis $(\mathrm{Na}+\mathrm{K})$ and weak acids $\left(\mathrm{CO}_{3}+\mathrm{HCO}_{3}\right)$ exceed strong acids $\left(\mathrm{Cl}+\mathrm{SO}_{4}+\mathrm{NO}_{3}\right)$ in a majority of groundwater samples. However, alkalis $(\mathrm{Na}+\mathrm{K})$ exceed alkaline earths $(\mathrm{Ca}+\mathrm{Mg})$ in the water sample from dug well DW17, while strong acid $\left(\mathrm{Cl}+\mathrm{SO}_{4}+\mathrm{NO}_{3}\right)$ exceeds weak acid $\left(\mathrm{CO}_{3}+\mathrm{HCO}_{3}\right)$ in the groundwater samples from dug wells DW4, DW8, DW25, DW26 and DW30.

This change in type of groundwater of the study area may be attributed to the influence of surface activities. Percolation of waste/wastewater from the surface rich in alkalis and strong acids might have caused such changes in groundwater. Ions such as $\mathrm{Cl}$ and $\mathrm{NO}_{3}$ usually do not take active part in the processes occurring during circulation and get directly added to groundwater. Possibilities of cation exchange increases when resident time of water is more, leading to strong water-rock interaction. However, in shallow aquifers of the study area, groundwater is under constant circulation and regularly gets recharged. Hence, possibilities of ion exchange during the circulation are negligible (Back 1966; Deutsch 1997; Saini et al. 2006; Pophare and Dewalkar 2007).

\subsection{Index of base exchange}

Control on the dissolution of undesirable constituents in water is impossible during subsurface 


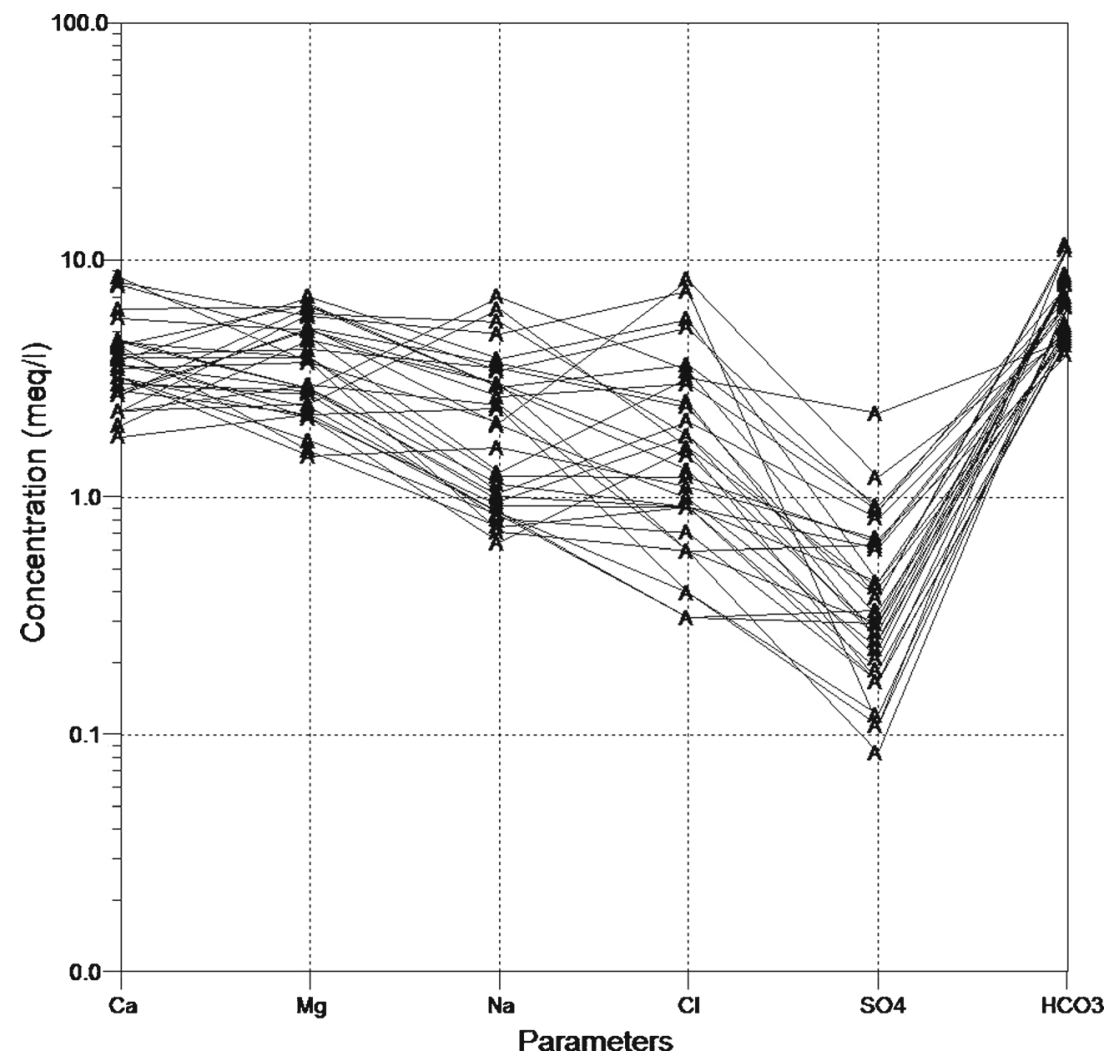

Figure 8. Schoeller's classification of the groundwater samples of the study area (after Schoeller 1955, 1967).

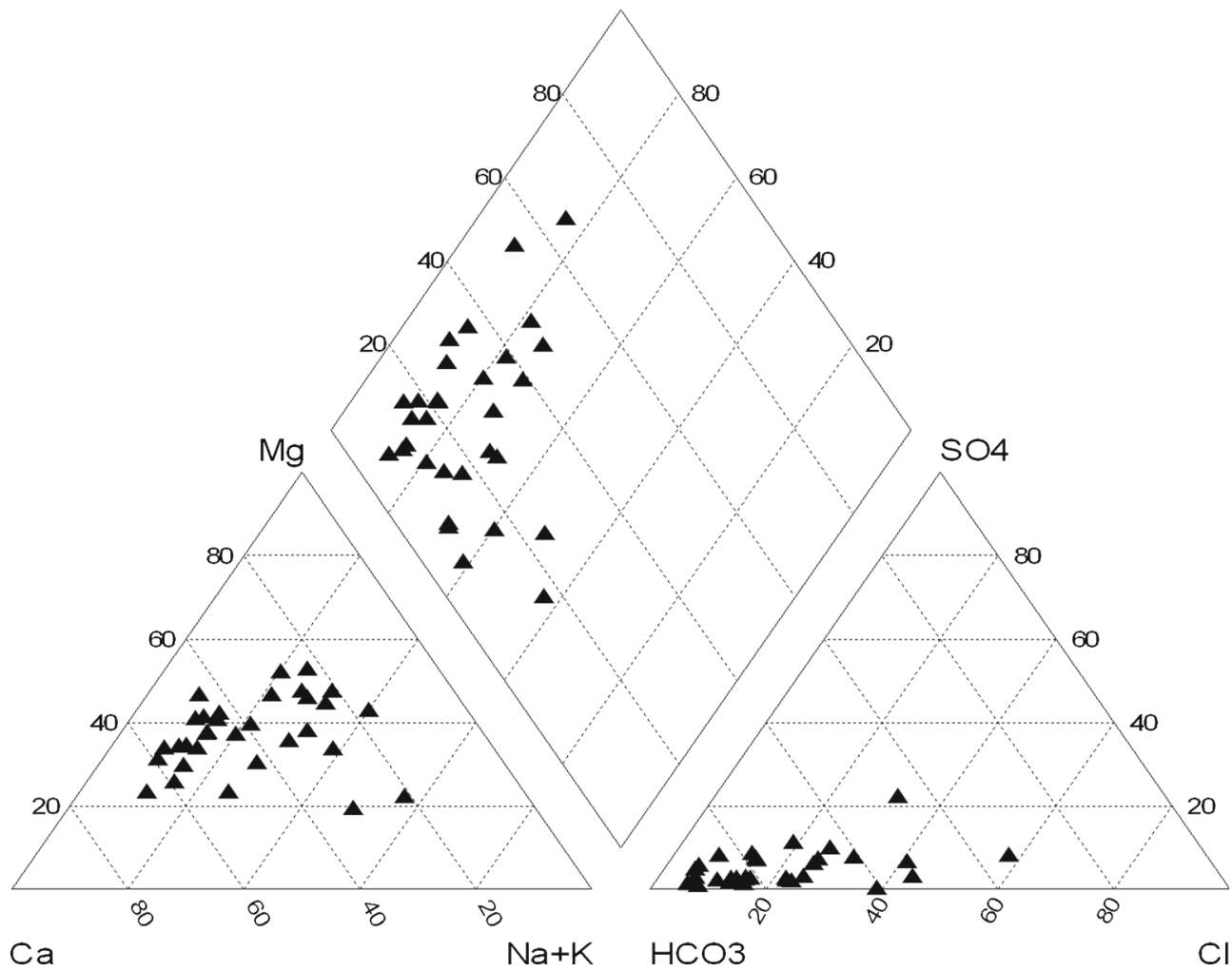

Figure 9. Chemical classification of groundwater samples from dug wells of the study area, average data of pre-monsoon season of 2008 (after Piper 1944, 1953). 
Table 5. Choloro-alkaline indices in the ground water samples of the study area.

\begin{tabular}{lrc}
\hline Dugwell no. & CAI-I & CAI-II \\
\hline DW1 & -0.62 & 0.49 \\
DW2 & -2.42 & 0.16 \\
DW3 & 0.05 & 0.77 \\
DW4 & 2.78 & 3.06 \\
DW5 & -1.84 & 0.26 \\
DW6 & -2.50 & 0.15 \\
DW7 & -0.15 & 0.73 \\
DW8 & 4.53 & 4.87 \\
DW9 & -0.38 & 0.80 \\
DW10 & 1.26 & 1.66 \\
DW11 & 2.09 & 2.73 \\
DW12 & 1.58 & 1.94 \\
DW13 & 0.11 & 1.05 \\
DW14 & 1.20 & 1.48 \\
DW15 & -0.36 & 0.73 \\
DW16 & 6.69 & 6.95 \\
DW17 & 1.28 & 2.82 \\
DW18 & -4.53 & 0.26 \\
DW19 & -0.97 & 1.03 \\
DW20 & -1.24 & 1.19 \\
DW21 & -0.53 & 0.77 \\
DW22 & -1.05 & 0.27 \\
DW24 & -3.57 & 2.03 \\
DW25 & 0.93 & 5.19 \\
DW26 & 4.92 & 7.85 \\
DW27 & 7.93 & 0.96 \\
DW28 & -2.26 & 2.12 \\
DW29 & 0.75 \\
DW30 & 3.32 \\
DW31 & 0.57 \\
DW33 & -00 \\
DW34 & -39 \\
\hline & & \\
\hline
\end{tabular}

run off. However, it is essential to understand various changes that groundwater undergoes during its circulation (Pojasek 1977; Johnson 1979). The mechanism of ion exchange between groundwater and its host environment during residence or circulation can be understood by the study of chloroalkaline indices CAI-I: $\mathrm{Cl}-(\mathrm{Na}+\mathrm{K}) / \mathrm{Cl}$ and CAIII: $\mathrm{Cl}-(\mathrm{Na}+\mathrm{K}) / \mathrm{SO}_{4}+\mathrm{HCO}_{3}+\mathrm{CO}_{3}+\mathrm{NO}_{3}$ (Schoeller 1955, 1967).

The chloro-alkaline indices can be either positive or negative depending on whether exchange of $\mathrm{Na}$ and $\mathrm{K}$ is from water with $\mathrm{Mg}$ and $\mathrm{Ca}$ in rock or vice-versa. Positive values of the ratios indicate a base-exchange reaction (chloro-alkaline equilibrium) and negative values indicate chloroalkaline disequilibrium and the reaction as a cation-anion exchange reaction (Sreedevi 2004). The chloro-alkaline indices of groundwater samples from the study area indicate that 47\% (15 samples) show positive CAI-I ratio, whereas, $53 \%$
(17 samples) show negative CAI-I ratio. However, all the groundwater samples of the study area show positive CAI-II ratio indicating that chloro-alkaline equilibrium exists in the groundwater of the study area (table 5).

\subsection{Gibbs diagram}

Gibbs (1970) proposed a diagram to understand the mechanism controlling groundwater chemistry and the relationship of chemical components of waters from their respective aquifer lithologies. This diagram is based on Gibbs ratio I: $\left(\mathrm{Cl} / \mathrm{Cl}+\mathrm{HCO}_{3}\right)$ for anions and ratio II: $(\mathrm{Na}+\mathrm{K}) /$ $(\mathrm{Na}+\mathrm{K}+\mathrm{Ca})$ for cations of water samples and consists of three distinct fields, viz., precipitation dominance, evaporation dominance, and rock dominance. Gibbs ratio-I and II, calculated for the groundwater samples of the study area plot separately against respective values of TDS and show rock dominance over the majority of groundwater samples, indicating interaction between aquifer lithology and groundwater (figure 10).

In WR-2 watershed, basalt is the main water bearing formation. These rocks are usually composed of chain silicates, pyroxene (partly amphibole), and feldspar group of minerals. The dissolution of these minerals mainly yields $\mathrm{Ca}, \mathrm{Mg}$ and $\mathrm{Na}$ ions to groundwater (Plummer and Back 1980; Katz and Choquette 1991; Pawar 1993; Pawar and Nikumbh 2007). The probable chemical reactions during water-rock interaction are as under:

$$
\underset{\text { Anorthite }}{\mathrm{CaAl}_{2} \mathrm{Si}_{2} \mathrm{O}_{8}}+\mathrm{H}_{2} \mathrm{O}+2 \mathrm{H}^{+}=\underset{\text { Kaolinite }}{\mathrm{Al}_{2} \mathrm{Si}_{2} \mathrm{O}_{5}(\mathrm{OH})_{4}}+\mathrm{Ca}^{++}
$$

$$
\begin{aligned}
& 5 \mathrm{Mg}_{2} \mathrm{SiO}_{4}+8 \mathrm{H}^{+}+2 \mathrm{H}_{2} \mathrm{O}=\mathrm{Mg}_{6}(\mathrm{OH})_{8} \mathrm{Si}_{4} \mathrm{O}_{10} \\
& \text { Olivine } \\
& \text { Serpentine } \\
& +4 \mathrm{Mg}^{++}+\mathrm{H}_{4} \mathrm{SiO}_{4}
\end{aligned}
$$

$$
\begin{aligned}
& \underset{\text { Pyroxene }}{\mathrm{CaFeAl}_{2} \mathrm{Si}_{3} \mathrm{O}_{12}(\mathrm{~s})+5 \mathrm{H}_{2} \mathrm{O}+6 \mathrm{CO}_{2}} \\
& =\mathrm{Al}_{2} \mathrm{Si}_{2} \mathrm{O}_{5}(\mathrm{OH})_{4}(\mathrm{~s})+\mathrm{Ca}^{++}+\mathrm{Mg}^{++} \\
& \quad \text { Kaolinite } \\
& +\mathrm{Fe}^{++}+6 \mathrm{HCO}_{3}^{-}+\mathrm{SiO}_{2}
\end{aligned}
$$

$2 \mathrm{NaAlSi}_{2} \mathrm{O}_{8}+9 \mathrm{H}_{2} \mathrm{O}+2 \mathrm{H}^{+}$

Albite

$$
=\mathrm{Al}_{2} \mathrm{Si}_{2} \mathrm{O}_{5}(\mathrm{OH})_{4}+2 \mathrm{Na}^{+}+4 \mathrm{H}_{4} \mathrm{SiO}_{4}
$$
Kaolinite

Concentration of $\mathrm{HCO}_{3}$ ion in groundwater is mainly influenced by the amount of $\mathrm{CO}_{2}$ dissolved 

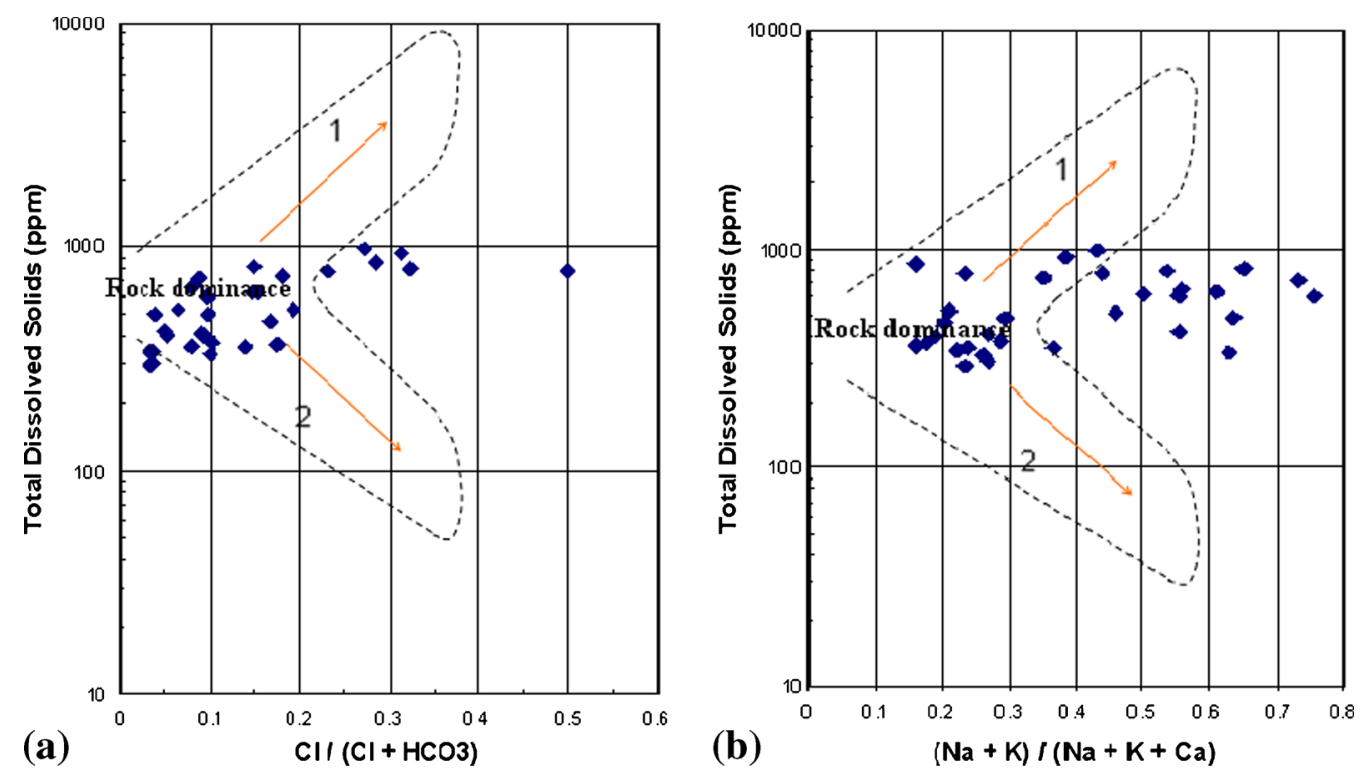

Figure 10. Mechanisms controlling chemistry of groundwater during pre-monsoon season of 2008. (a) Evaporation dominance and (b) precipitation dominance (after Gibbs 1970).

in water from atmosphere and decay of organic matter. The concentration of $\mathrm{K}$ in groundwater of basaltic aquifer is generally very low. It is liberated with great difficulty from K-feldspars as these minerals are very resistant to the attack by water. Potassium has a strong tendency to be reincorporated into the solid weathering product (Tardy 1971; Pedro and Siefferman 1979; Pawar and Nikumbh 2007). In basalts, there is no apparent source of $\mathrm{Cl}, \mathrm{SO}_{4}$ and $\mathrm{NO}_{3}$. The groundwater in basaltic terrain of the study area which is rich in these ions is indicative of anthropogenic contamination (Weijden and Pacheco 2006; Tiwari et al. 2007, 2008).

\section{Quality of groundwater for drinking and irrigation purposes}

The groundwater quality assessment for drinking purpose was carried out based on the drinking water standards prescribed by Bureau of Indian Standards (BIS 2003) for various parameters and is summarized in table 6 . It is observed that $\mathrm{pH}$ and concentrations of parameters such as $\mathrm{SO}_{4}$ and $\mathrm{F}$ in groundwater are within the desirable limits and have less impact on the quality of groundwater. The potability of groundwater is mainly affected by the parameters like TA, $\mathrm{Ca}, \mathrm{Mg}, \mathrm{TH}, \mathrm{NO}_{3}$ and TDS, as more than $50 \%$ of dug well waters have concentrations of these parameters beyond the desirable limits for drinking purpose (table 6). However, the groundwater of four dug wells DW4, DW8, DW16 and DW26 cannot be utilised for drinking purpose as it has crossed the maximum permissible limit of $600 \mathrm{mg} / \mathrm{l}$ for $\mathrm{TH}$, in absence of alternate source. The groundwater in $19 \mathrm{dug}$ wells, classified under the parameter $\mathrm{NO}_{3}$ is also not suitable for drinking purpose as there is no relaxation under maximum permissible limit in case of alternate source (table 6).

The field observations during the present study have indicated that anthropogenic activities like open unlined sewerages, improper disposal of cow dung for manure in the vicinity of groundwater sampling source, excessive use of fertilizer in agriculture field for orange cultivation, etc., are the main reasons for nitrate contamination in groundwater of the study area. These observations suggest that overall, the groundwater of the study area, in more than $50 \%$ dug wells is not suitable for drinking purpose (table 6). This indicates that the water quality deterioration in the study area is due to groundwater overdraft and point to nonpoint source contamination from agriculture and domestic uses.

Overlay analysis has been carried out using weighted average method in GIS software (Mapinfo $6.5)$ to identify the risk associated with the groundwater from a particular dug well. This method allows analysis of geospatial data, where the vector parameters overlay by using simple statistical correlation. Logically the weights were assigned as ' 1 ' to each parameter, viz., EC, $\mathrm{Ca}, \mathrm{Mg}, \mathrm{NO}_{3}$, TDS, $\mathrm{TA}$ and $\mathrm{TH}$ of groundwater from each dug well. The cumulative weighted layer was derived at the end and categorized in six zones (table 7, figure 11).

The suitability of groundwater for irrigation purpose is examined using EC, percent sodium (\% Na), sodium adsorption ratio (SAR), soluble sodium 
Table 6. Classification based on BIS drinking water standards (after BIS 2003).

\begin{tabular}{|c|c|c|c|}
\hline Parameters & $\begin{array}{l}\text { Desirable } \\
\text { limit }\end{array}$ & $\begin{array}{l}\text { Dug wells in which the groundwater } \\
\text { exceeding desirable limit }\end{array}$ & $\begin{array}{l}\text { Total no. of } \\
\text { such dug wells }\end{array}$ \\
\hline $\mathrm{pH}$ & $6.5-8.5$ & Nil & Nil \\
\hline TDS (mg/l) & 500 & $\begin{array}{l}\text { DW4, DW8, DW11-12, DW16-17, } \\
\text { DW19-21, DW24-28, DW30, DW34 }\end{array}$ & 16 \\
\hline $\mathrm{TA}$ as $\mathrm{CaCO}_{3}(\mathrm{mg} / \mathrm{l})$ & 200 & DW1-8, DW10-22, DW24-31, DW33-34 & 31 \\
\hline $\mathrm{TH}$ as $\mathrm{CaCO}_{3}(\mathrm{mg} / \mathrm{l})$ & 300 & $\begin{array}{l}\text { DW1, DW4, DW8, DW10-21, DW24-26, } \\
\text { DW28, DW30, DW34 }\end{array}$ & 21 \\
\hline $\mathrm{Ca}(\mathrm{mg} / \mathrm{l})$ & 75 & $\begin{array}{l}\text { DW3-4, DW8, DW10-14, DW16-17, } \\
\text { DW24-26, DW30 }\end{array}$ & 14 \\
\hline $\mathrm{Mg}(\mathrm{mg} / \mathrm{l})$ & 30 & $\begin{array}{l}\text { DW1, DW4, DW8, DW10-13, DW15-22, } \\
\text { DW24-26, DW28-31, DW34 }\end{array}$ & 23 \\
\hline $\mathrm{Cl}(\mathrm{mg} / \mathrm{l})$ & 250 & DW16, DW26 & 2 \\
\hline $\mathrm{SO}_{4}(\mathrm{mg} / \mathrm{l})$ & 200 & Nil & Nil \\
\hline $\mathrm{NO}_{3}(\mathrm{mg} / \mathrm{l})$ & 45 & $\begin{array}{l}\text { DW3-4, DW8, DW10-13, DW15, } \\
\text { DW19-21, DW24-25, DW27-31, DW34 }\end{array}$ & 19 \\
\hline $\mathrm{F}(\mathrm{mg} / \mathrm{l})$ & 1.0 & Nil & Nil \\
\hline
\end{tabular}

Table 7. Categorisation of dug wells based on risk associated to human health in WR-2 watershed.

\begin{tabular}{lccl}
\hline Category of risk & $\begin{array}{c}\text { Resultant } \\
\text { assigned weight }\end{array}$ & $\begin{array}{c}\text { Total dug } \\
\text { wells }\end{array}$ & Dugwell numbers \\
\hline $\begin{array}{l}\text { Very high risk dug wells } \\
\text { High risk dug wells }\end{array}$ & 8 & 1 & DW27 \\
Severe risk dug wells & 6 & 2 & DW24, DW34 \\
Moderate high risk dug wells & 5 & 6 & DW8, DW17, DW20, DW25, DW28, DW30 \\
Moderate risk dug wells & 4 & 7 & DW4, DW11, DW12, DW16, DW19, DW21, DW26 \\
No risk dug wells & $>4$ & 4 & DW10, DW13, DW18, DW22 \\
& & 14 & DW5, DW7, DW23, DW32, DW2, DW6, DW1, DW3, \\
& & & DW9, DW14, DW15, DW29, DW31, DW33 \\
\hline
\end{tabular}

percentage (SSP), residual sodium carbonate (RSC), Kelly's ratio (KR), magnesium ratio (MR), corrosivity ratio (CR), and permeability index (PI) values of the groundwater samples (tables 8 and 9). The level of salinity hazard based on EC, and sodium hazard based on SAR value is assessed using US Salinity diagram (USSL 1954) (figure 12).

\subsection{Per cent sodium (\% Na)}

Percent sodium parameter in groundwater is computed to evaluate its suitability for irrigation (Wilcox 1948, 1955). Excess Na combining with carbonate will lead to formation of alkaline soils, while $\mathrm{Na}$ with $\mathrm{Cl}$ forms the saline soils. Either of the soils do not support growth of crops (Sreedevi 2002; Pandian and Sankar 2007). As per the Bureau of Indian Standards, $\mathrm{Na}$ up to $60 \%$ in groundwater is permissible for irrigation purpose (BIS 2003). $\% \mathrm{Na}$ is calculated by the following formula using values in meq/l:

$$
\% \mathrm{Na}=\left[\frac{\mathrm{Na}}{\mathrm{Ca}+\mathrm{Mg}+\mathrm{Na}+\mathrm{K}}\right] \times 100 .
$$

In groundwater samples of the study area, $\% \mathrm{Na}$ in $50 \%$ samples is within excellent category, $41 \%$ in good category, while only $9 \%$ samples are falling in permissible category (table 9 ).

\subsection{Sodium absorption ratio (SAR)}

Suitability of groundwater for agricultural purpose is determined by SAR, as it is responsible for sodium hazard (USSL 1954, 1973). Sodium and salinity hazards are the two important parameters, which can indicate suitability of water for irrigation usage (Sreedevi 2002). SAR is calculated by the following formula using values in meq/l:

$$
\mathrm{SAR}=\frac{\mathrm{Na}}{\sqrt{(\mathrm{Ca}+\mathrm{Mg}) / 2}} .
$$

In groundwater samples of the study area SAR values indicate that all the samples fall in $\mathrm{C} 2-\mathrm{S} 1$ and C3-S1 category and are suitable for irrigation purposes (table 9, figure 12) (USSL 1954, 1973).

Possibility of sodium hazard to the soil is low (S1) as SAR values of groundwater samples from 


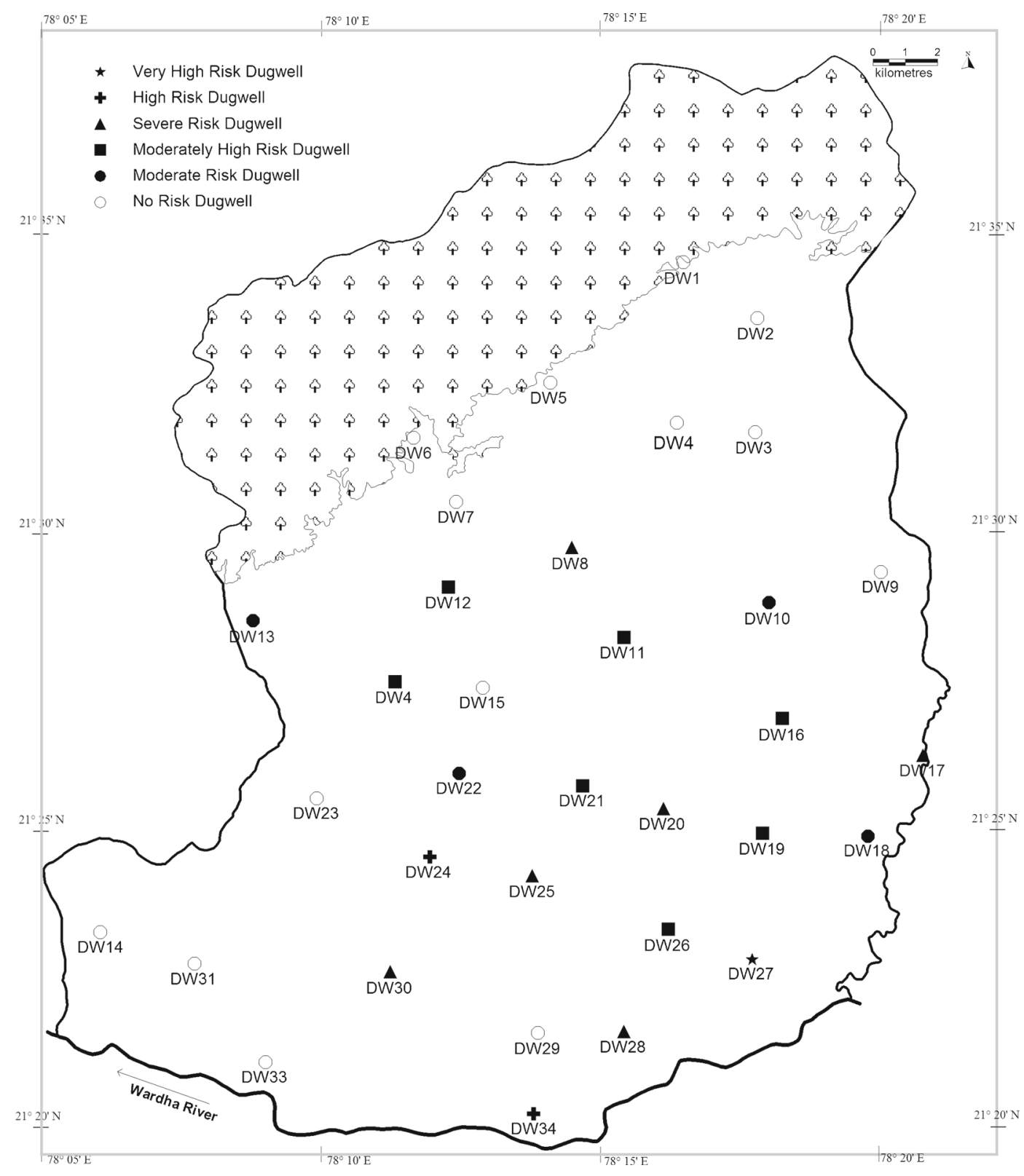

Figure 11. Groundwater quality and risk zone map of WR-2 watershed.

all the dug wells are less than 10 (table 8). The low SAR values in the area are due to the low concentration of sodium in groundwater as compared to the alkaline earth, i.e., $\mathrm{Ca}$ and $\mathrm{Mg}$ ions. However, EC values of most of the samples fall under the category of medium (C2) and high (C3) salinity hazard zone indicating that special crop and water management practices are required for utilizing such water for irrigation purpose (figure 12).

\subsection{Soluble sodium percentage (SSP)}

Sodium by the process of base-exchange replaces calcium in the soil, which in turn lowers soil permeability. SSP for water samples was calculated by the following formula using values in meq/l:

$$
\mathrm{SSP}=\frac{\mathrm{Na} \times 100}{\mathrm{Ca}+\mathrm{Mg}+\mathrm{Na}}
$$

In groundwater samples of the study area, about $97 \%$ samples are suitable for irrigation while only $3 \%$ samples fall in unsuitable category (table 9 ).

\subsection{Residual sodium carbonate (RSC)}

RSC is the $\mathrm{CO}_{3}$ and $\mathrm{HCO}_{3}$ amount in alkaline earths chiefly $\mathrm{Ca}$ and $\mathrm{Mg}$, in excess of permissible limits, which affects irrigation adversely 
Table 8. \%Na, SAR, SSP, RSC, KR, MR, CR and PI in groundwater samples of the study area.

\begin{tabular}{|c|c|c|c|c|c|c|c|c|}
\hline Dugwell no. & $\% \mathrm{Na}$ & SAR & SSP & $\mathrm{RSC}$ & $\mathrm{KR}$ & MR & $\mathrm{CR}$ & PI \\
\hline DW1 & 8.95 & 0.37 & 8.96 & -0.91 & 0.10 & 51.41 & 0.63 & 40.67 \\
\hline DW2 & 14.53 & 0.53 & 14.55 & 0.27 & 0.17 & 35.07 & 0.33 & 54.07 \\
\hline DW3 & 11.28 & 0.44 & 11.31 & -1.26 & 0.13 & 26.67 & 0.91 & 43.77 \\
\hline DW4 & 9.15 & 0.50 & 9.17 & -7.88 & 0.10 & 37.56 & 3.29 & 24.78 \\
\hline DW5 & 12.47 & 0.50 & 12.52 & 0.41 & 0.14 & 39.87 & 0.40 & 49.46 \\
\hline DW6 & 14.53 & 0.54 & 14.57 & -0.12 & 0.17 & 44.25 & 0.33 & 52.23 \\
\hline DW7 & 14.52 & 0.56 & 14.60 & -0.63 & 0.17 & 40.07 & 0.92 & 49.29 \\
\hline DW8 & 21.27 & 1.35 & 21.29 & -5.93 & 0.27 & 50.55 & 5.24 & 37.43 \\
\hline DW9 & 25.53 & 1.05 & 25.57 & -0.68 & 0.34 & 31.65 & 1.13 & 57.37 \\
\hline DW10 & 11.44 & 0.50 & 11.47 & -2.18 & 0.13 & 39.03 & 1.82 & 38.82 \\
\hline DW11 & 19.79 & 1.15 & 19.83 & -2.82 & 0.25 & 46.83 & 3.06 & 40.85 \\
\hline DW12 & 11.08 & 0.51 & 11.09 & -3.27 & 0.12 & 46.23 & 2.13 & 35.08 \\
\hline DW13 & 13.38 & 0.62 & 13.55 & -1.26 & 0.16 & 49.80 & 1.25 & 41.94 \\
\hline DW14 & 9.41 & 0.36 & 9.43 & -1.75 & 0.10 & 34.85 & 1.62 & 40.35 \\
\hline DW15 & 14.84 & 0.63 & 14.85 & -1.19 & 0.17 & 44.45 & 0.93 & 45.09 \\
\hline DW16 & 25.81 & 1.86 & 26.14 & -2.25 & 0.35 & 41.87 & 7.39 & 44.35 \\
\hline DW17 & 47.53 & 3.62 & 48.34 & 3.93 & 0.94 & 38.51 & 3.45 & 71.67 \\
\hline DW18 & 31.12 & 1.65 & 31.22 & 1.78 & 0.45 & 69.74 & 0.62 & 61.37 \\
\hline DW19 & 24.34 & 1.37 & 24.38 & -0.43 & 0.32 & 70.12 & 1.31 & 48.92 \\
\hline DW20 & 27.69 & 1.52 & 27.72 & 0.38 & 0.38 & 64.20 & 1.52 & 54.18 \\
\hline DW21 & 20.22 & 1.01 & 20.23 & 0.31 & 0.25 & 65.76 & 1.00 & 49.19 \\
\hline DW22 & 31.51 & 1.50 & 31.63 & 1.54 & 0.46 & 56.30 & 0.60 & 65.51 \\
\hline DW24 & 29.74 & 1.72 & 29.79 & -0.10 & 0.42 & 51.20 & 2.42 & 54.16 \\
\hline DW25 & 26.15 & 1.65 & 26.17 & -3.99 & 0.35 & 64.80 & 5.64 & 44.00 \\
\hline DW26 & 14.33 & 0.83 & 14.44 & -7.30 & 0.17 & 30.60 & 8.26 & 29.94 \\
\hline DW27 & 56.26 & 4.00 & 56.42 & 3.84 & 1.29 & 51.77 & 1.62 & 83.23 \\
\hline DW28 & 31.59 & 1.84 & 31.66 & 0.11 & 0.46 & 65.76 & 2.53 & 56.17 \\
\hline DW29 & 14.66 & 0.59 & 14.71 & -0.90 & 0.17 & 48.26 & 0.91 & 47.28 \\
\hline DW30 & 21.00 & 1.25 & 21.09 & -3.90 & 0.27 & 59.64 & 3.67 & 40.24 \\
\hline DW31 & 12.33 & 0.48 & 12.34 & -1.01 & 0.14 & 47.52 & 0.71 & 45.60 \\
\hline DW33 & 35.90 & 1.66 & 36.86 & 2.27 & 0.58 & 55.25 & 0.40 & 76.24 \\
\hline DW34 & 39.95 & 2.70 & 39.98 & 2.77 & 0.67 & 72.04 & 1.84 & 64.18 \\
\hline Minimum & 8.95 & 0.36 & 8.96 & -7.88 & 0.10 & 26.67 & 0.33 & 24.78 \\
\hline Maximum & 56.26 & 4.00 & 56.42 & 3.93 & 1.29 & 72.04 & 8.26 & 83.23 \\
\hline Average & 21.95 & 1.21 & 22.06 & -1.00 & 0.32 & 49.11 & 2.12 & 49.61 \\
\hline
\end{tabular}

(Eaton 1950; Richards 1954). Continued usage of high residual sodium carbonate waters affects the yield of crops. High concentration of bicarbonate may result in precipitation of $\mathrm{Ca}$ and $\mathrm{Mg}$ bicarbonates from the soil solution, increasing relative proportion of $\mathrm{Na}$ and causing sodium hazard. RSC refers to residual alkalinity and can be calculated by the following formula using values in meq/l:

$$
\mathrm{RSC}=\left(\mathrm{HCO}_{3}+\mathrm{CO}_{3}\right)-(\mathrm{Ca}+\mathrm{Mg})
$$

RSC values indicate that about $82 \%$ groundwater samples of the study area are in the safe category, $9 \%$ samples are suitable, while another 9\% samples fall in the unsuitable category for irrigation purposes (table 9).

\subsection{Kelly's ratio (KR)}

The level of $\mathrm{Na}$ measured against $\mathrm{Ca}$ and $\mathrm{Mg}$ is known as Kelley's ratio based on which irrigation waters can be rated (Kelley 1946; Paliwal 1967). Excess sodium in waters produces undesirable effects of changing soil properties and reducing soil permeability (Kelley 1951; Tijani 1994). Kelley's ratio is taken as an indication of alkali hazard in water (Handa 1981). It is determined form the following formula using values in meq/l:

$$
\mathrm{KR}=\frac{\mathrm{Na}}{\mathrm{Ca}+\mathrm{Mg}}
$$

In groundwater samples of the study area, only $3 \%$ groundwater samples are unsuitable for irrigation, whereas $97 \%$ samples are suitable for irrigation (table 9).

\subsection{Magnesium ratio (MR)}

Magnesium hazard ratio is the excess amount of $\mathrm{Mg}$ over $\mathrm{Ca}$ and $\mathrm{Mg}$ amount, whereas normally the 


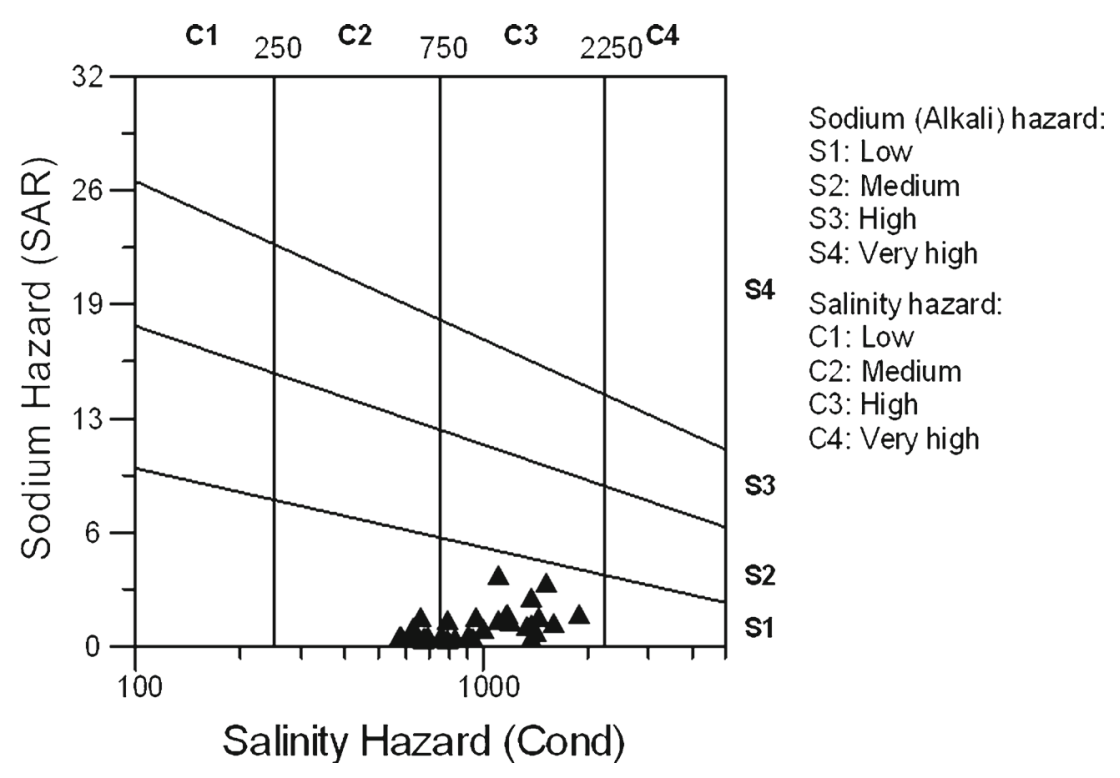

Figure 12. SAR vs. conductivity plot of groundwater samples from dug wells of the study area during pre-monsoon season of 2008 (after USSL 1954, 1973).

level of $\mathrm{Ca}$ and $\mathrm{Mg}$ will be in a state of equilibrium (Lloyd and Heathcote 1985; Sreedevi 2002). Excess $\mathrm{Mg}$ affects the quality of soil resulting in poor agricultural returns. MR is calculated by the formula using values in meq/l:

$$
\mathrm{MR}=\frac{\mathrm{Mg} \times 100}{\mathrm{Ca}+\mathrm{Mg}} .
$$

In groundwater samples of the study area about $56 \%$ samples are found suitable, while $44 \%$ are found unsuitable for irrigation purpose (table 9).

\subsection{Corrosivity ratio (CR)}

The corrosivity ratio is important to know whether the water can be transported through metallic pipes or not. The groundwater with $\mathrm{CR}$ values of $<1$ is considered to be safe for transport of water in any pipe. If the corrosivity ratio is $>1$, only noncorrosive pipes have to be used for transporting water (Ryner 1944; Raman 1985). The intensity of corrosion depends upon certain physical factors like temperature, pressure, and flow velocity of water (Ayer and Westcot 1985). High concentrations of chloride and sulphate also increase the corrosion rate (Ryner 1944; Raman 1985). The corrosivity ratio is calculated by the following formula using values in meq/l:

$$
\mathrm{CR}=\frac{(\mathrm{Cl} / 35.5)+2\left(\mathrm{SO}_{4} / 96\right)}{2\left(\mathrm{HCO}_{3}+\mathrm{CO}_{3} / 100\right)}
$$

In groundwater samples of the study area, about $38 \%$ samples fall under good category while $62 \%$ samples are corrosive and not suitable for transportation through metal pipes (table 9).
Although it is pertinent that the quality of groundwater in shallow aquifers of WR-2 watershed, tapped by dug wells is suitable for irrigation purpose, high concentrations of $\mathrm{Ca}, \mathrm{Mg}, \mathrm{TH}, \mathrm{TA}$ and $\mathrm{SO}_{4}$ in it may affect the quality of soil at places.

\subsection{Permeability index (PI)}

The soil permeability is affected by long term use of irrigation water and is influenced by $\mathrm{Na}, \mathrm{Ca}, \mathrm{Mg}$ and $\mathrm{HCO}_{3}$ contents of the soil. The permeability index (PI), as developed by Doneen $(1962,1964)$ indicates the suitability of groundwater for irrigation. It is calculated as under using values in meq/l:

$$
\mathrm{PI}=\left[\frac{\left(\mathrm{Na}+\sqrt{\mathrm{HCO}_{3}}\right)}{\mathrm{Ca}+\mathrm{Mg}+\mathrm{Na}}\right] \times 100 .
$$

According to permeability indices, groundwater can be divided into Class I, Class II and Class III types. Class I and Class II water types are suitable for irrigation with $75 \%$ or more of maximum permeability, and Class III types of water with $25 \%$ maximum permeability. The PI values of groundwater samples range from $29.94 \%$ to $83.23 \%$ and thus, on the basis of Doneen's chart all groundwater samples of the study area are suitable for irrigation purpose except at dug well DW4 where PI was $24.78 \%$ (tables 8 and 9) (Doneen 1962, 1964).

\section{Discussion and conclusions}

Groundwater from the shallow aquifers of WR-2 watershed is utilized for irrigation and domestic 
Table 9. Classification of groundwater samples based on \%Na, SAR, SSP, RSC, KR, $M R, C R$ and $P I$.

\begin{tabular}{llrll}
\hline Ratio & Range $(\mathrm{meq} / \mathrm{l})$ & No. of samples & Percentage & Category \\
\hline$\% \mathrm{Na}$ & $<20$ & 16 & 50 & Excellent \\
& $20-40$ & 13 & 41 & Good \\
& $40-60$ & 3 & 9 & Permissible \\
& $60-80$ & 0 & 0 & Doubtful \\
& $>80$ & 0 & 0 & Unsuitable \\
SAR & $<10$ & 32 & 100 & Excellent \\
& $10-18$ & 0 & 0 & Good \\
& $18-26$ & 0 & 0 & Fair \\
& $>26$ & 0 & 0 & Unsuitable \\
SSP & $<50$ & 31 & 97 & Good \\
& $>50$ & 1 & 3 & Unsuitable \\
RSC & $<1.25$ & 26 & 82 & Safe \\
& $1.25-2.5$ & 3 & 9 & Suitable \\
& $>0.5$ & 3 & 9 & Unsuitable \\
KR & $<1$ & 31 & 97 & Good \\
& $>1$ & 1 & 3 & Unsuitable \\
MR & $<50$ & 18 & 56 & Suitable \\
& $>50$ & 14 & 44 & Unsuitable \\
CR & $<1$ & 12 & 38 & Good \\
PI & $>1$ & 20 & 62 & Unsuitable \\
& Up to $75 \%$ & 31 & 3 & Good \\
& $<25 \%$ & 1 & Unsuitable \\
\hline
\end{tabular}

purposes. The long term (1977-2010) and short term (2007-2010) record of both DTWL and spot $\mathrm{EC}$ in the dug wells of these aquifers indicate that the decline in DTWL is directly proportional to the rising EC values of the groundwater. The declining DTWL trend indicates progressive scarcity of groundwater, whereas rising EC values indicate deterioration of groundwater quality in the dug wells of phreatic shallow aquifers of WR-2 watershed. Overlay analysis of DTWL shows that the areas in the central and southern parts of WR-2 watershed have deeper DTWL and are more susceptible to contamination as compared to the rest of the areas and have more groundwater overdraft than the natural recharge. The groundwater exploration in the study area has been carried out to a depth of $172 \mathrm{~m}$, where unconfined aquifers comprising of fractured massive and vesicular basalt occur up to the depth from 10 to $41 \mathrm{~m}$ with varying thickness. The static water level (SWL) varies from 4.35 to $36 \mathrm{~m}$ bgl. A multi-layer fractured aquifer system exists in Deccan Trap basaltic terrain where groundwater occurs only in interconnected fractured zones. Considering this aspect, the up-coning of deeper aquifer due to groundwater exploitation may not be possible, which is often observed in unconsolidated/consolidated alluvium formation.

In the study area, there are several factors interrelated to each other causing over-exploitation of groundwater from the shallow aquifers of WR-2 watershed. This includes the propensity of the local farmers to take cash crop of oranges mostly through traditional irrigation practices, ignoring the depleting groundwater levels in the aquifers, although the traditional technique of flood irrigation causes more groundwater draft than the modern irrigation techniques like drip and sprinkler method. The specific yield of basaltic aquifer in WR-2 watershed is meager and takes about 24 hours to recoup the dug after the pumping is stopped. Besides this, the irregular rainfall pattern over the years causes reduced runoff, which in turn reduces the base flow and ultimately natural recharge to the groundwater resources in the aquifers becomes negligible. These aspects result in depletion of groundwater level in the shallow aquifers of WR-2 watershed. Moreover, excessive use of pesticides and fertilizers has already deteriorated the quality of groundwater, causing leaching of soil and increase in the soil salinity. All these factors lead to a vicious cycle of groundwater overexploitation and its quality deterioration in the WR-2 watershed (figure 13).

The study of groundwater quality in WR-2 watershed indicates that groundwater from shallow aquifer tapped by more than $50 \%$ dug wells is not suitable for drinking and domestic purposes. This is due to higher concentration of parameters like $\mathrm{Ca}, \mathrm{Mg}, \mathrm{NO}_{3}$, TDS, TA and $\mathrm{TH}$, which are beyond the permissible limit. The higher 


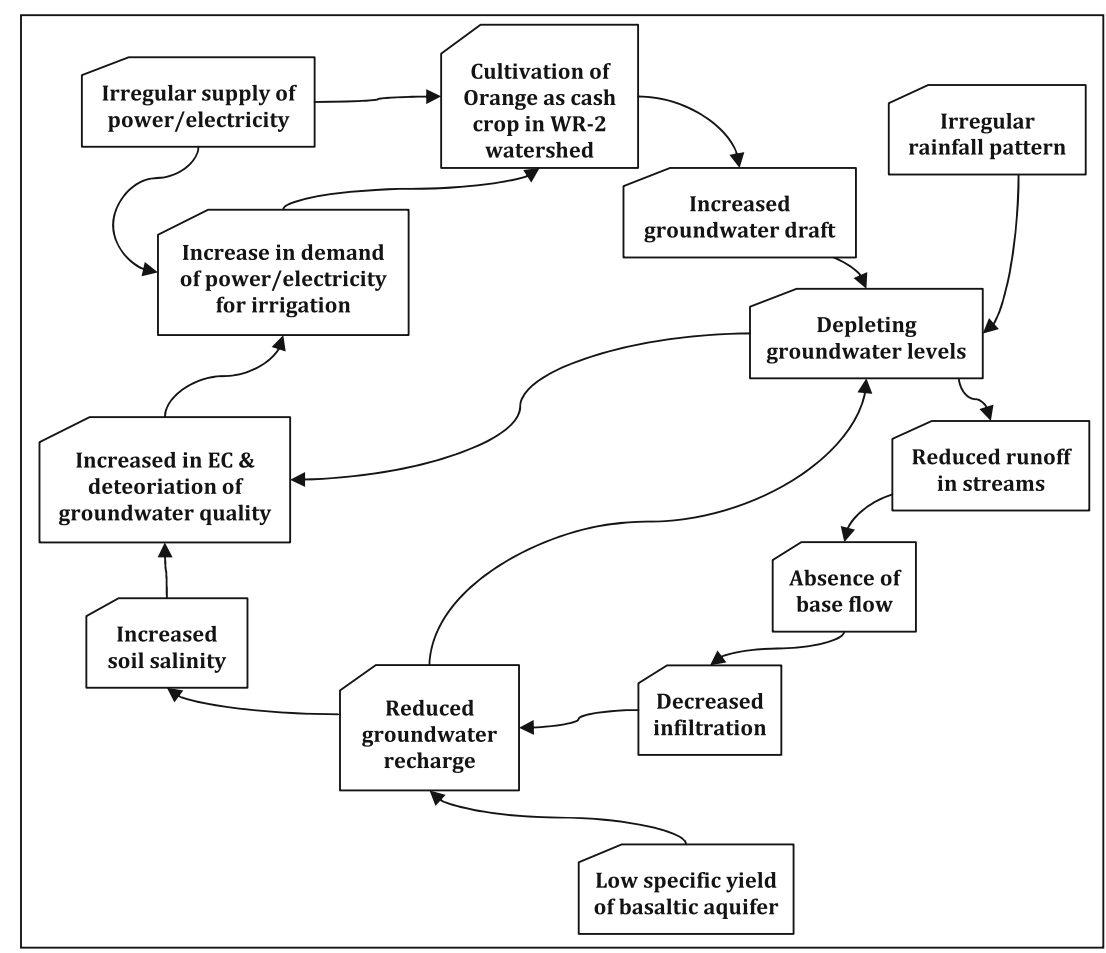

Figure 13. Vicious cycle of groundwater over-exploitation in the WR-2 watershed.

concentrations of these parameters in the groundwater of the study area has led to an increase in its EC values that adversely affect the quality of soil at places. This can be attributed to high susceptibility of groundwater sources to contamination due to anthropogenic influences of agricultural backflow and sewage effluent. The groundwater, though mostly suitable for irrigation purpose, is saturated with respect to mineral equilibrium and has a tendency towards chemical scale formation. Moreover, the CR values indicate that $62 \%$ of groundwater in the dug wells is corrosive in nature and not suitable for transport through metal pipes.

The correlation of observed chemical parameters and their zone/village-wise distribution indicate that the value of TH is high in the dug wells located towards northern and SE parts of the WR-2 watershed (i.e., at Temburkheda, Tiwsaghat, Surali, and Wadegaon villages). The EC was observed beyond permissible limit towards the central, southern, and eastern parts of the watershed (i.e., in dug wells at Tiwsaghat, Temburkheda, Warud, Surali, Chandas, Mangruli, Wadegaon, and Loni villages). High concentrations of $\mathrm{NO}_{3}$ was observed throughout the watershed, in the dug wells located at Malkapur, Tiwsaghat, Temburkheda, Dhanodi, Warud, Bahada, Manikpur, Jarud, Chinchgavhan, Amdapur, Davaegaon, Karajgaon, Mangruli, Wadala, Gadegaon, Nandgaon, Loni, Mamdapur, and Haturna villages. This may be attributed to the anthropogenic contamination of the groundwater sources in the entire watershed area.

In view of the above, it is very essential to take urgent steps to arrest the over-exploitation of groundwater. It is observed that the entire study area of WR-2 watershed is experiencing the vicious cycle of groundwater over-exploitation. This cycle is mainly based on the wrong agriculture practices, irregular monsoon rainfall pattern, typical basaltic aquifers, and irregular electric supply, etc. To break this cycle, it is recommended to change the cropping pattern in the entire WR-2 watershed area. Presently, there are about $84,53,349$ orange trees irrigated by groundwater through 12,879 irrigation wells. This cash crop can be supplemented with other crops such as cotton, oil seeds, pulses, vegetables, etc., which will reduce the water requirement considerably leading to break this vicious cycle.

It is recommended that participatory groundwater management practices and modern irrigation techniques like drip or sprinkler method should be adopted for irrigation in this area. This will possibly reduce groundwater draft by $4.64 \mathrm{Mm}^{3}$ /year and save $30 \%$ of groundwater. Further, the use of some advanced agriculture techniques like Aquaferti seed drill, Raised bed technology, Laser leveling, Biogas slurry, System of Rice Intensification (SRI), and combination of all techniques in water management can improve the crop yields by $17-$ $47 \%$, which in turn will save $11-43 \%$ of irrigation 
cost, groundwater, irrigation time, and electrical energy. Another management strategy to improve efficiency of water use is to utilise Pipe Distribution Network (PDN) instead of Canal Distribution Network $(\mathrm{CDN})$. By virtue of PDN the water use efficiency can be improved up to $70-80 \%$ from existing efficiency of $40 \%$ in the study area of WR-2 watershed.

As part of the participatory groundwater management approach, the stakeholders, people, and administrators should come forward for abovereferred interventions by strengthening collaboration and increasing confidence amongst them, before the system deteriorates. Although, the relation between over-exploitation of groundwater and its quality has been observed and established in the study area of WR-2 watershed, it requires detailed investigation. A dense and strong monitoring network for detailed long term water level and quality measurements and rainwater harvesting and other artificial recharge techniques should be implemented effectively to arrest declining water level and improving groundwater quality. The rising trends of EC in such watersheds/areas can be used as an indicator of groundwater over-exploitation. The results can be used for further study of similar over-exploited watersheds, in Amravati district, in particular and Maharashtra State, in general.

\section{Acknowledgements}

Authors are thankful to anonymous reviewers for critically reviewing the manuscript. BRL is thankful to the Chairman, CGWB, Faridabad and Regional Director, CGWB, Nagpur for permitting to carry out this work.

\section{References}

APHA 1998 Standard methods for the examination of water and waste water; American Public Health Association, Water Pollution Control Federation, Washington DC, 20th edn, pp. 10-161.

Appelo C A J and Postma D 1993 Geochemistry, groundwater and pollution; A A Balkema Publ., Rotterdam, The Netherlands, pp. 45-49.

Ayer R S and Westcot D W 1985 Water quality for agriculture, irrigation and drainage; Paper no. 29, Rev. I FAQ Rome 174.

Back W 1966 Hydrochemical facies and groundwater flow patterns in northern part of Atlantic coastal plain; USGS Professional Paper 498-A.

Bagher R M and Rasoul M R 2010 Effect of groundwater table decline on groundwater quality in Sirjan Watershed; Arabian J. Sci. Engg 35(1B) 197-210.

BIS 2003 Indian standard drinking water specification (first revision incorporating amendment no.1 January 1993 and amendment no. 2 September 2003), IS10500: 1991 edn
2.2 (2003-09); Bureau of Indian Standards, New Delhi, India.

CGWB 1998a A report on artificial recharge to groundwater in orange growing areas, watershed WR-2, Taluka Warud, District Amravati, Maharashtra; Central Ground Water Board, Central Region, Nagpur, Report No. 884/ARP/1998, 190p.

CGWB 1998b Detailed guidelines for implementing the groundwater estimation methodology - 1997; Central Ground Water Board, Ministry of Water Resources, Govt. of India, 219p.

CGWB 1999 Integrated water resources development: A plan for action; Report of the National Commission for Integrated Water Resources Development Plan, Ministry of Water Resources, Govt. of India, 1 515p.

CGWB 2007 Manual on artificial recharge of groundwater; Central Ground Water Board, Ministry of Water Resources, Govt. of India, 185p.

CGWB 2010 Groundwater Year Book - 2009-10: Maharashtra and Dadra, Nagar and Haveli; Central Ground Water Board, Central Region, Nagpur, Report No. 1678/ GWM/2011, pp. 10-26.

CGWB 2012 Report on drilling, construction and commissioning of 88 piezometers in Vidarbha region, Maharashtra; Report No.1690/GWM/2012 (AAP-2011-2012), Central Ground Water Board, Central Region, Nagpur, Ministry of Water Resources, Govt. of India, 42p.

CGWB and GSDA 2005 Report on dynamic groundwater resources of Maharashtra as on March 2005; Central Ground Water Board, Central Region, Nagpur and Groundwater Surveys \& Development Agency, 332p.

CGWB and GSDA 2009 Report on dynamic groundwater resources of Maharashtra as on March 2008; Central Ground Water Board, Central Region, Nagpur and Groundwater Surveys \& Development Agency, 228p.

Deutsch W J 1997 Groundwater geochemistry: Fundamentals and applications to contamination; Lewis Publ. New York, 221p.

Diamantopoulou P and Voudouris K 2008 Optimization of water resources management using SWOT analysis: The case of Zakynthos Island, Ionian Sea, Greece; Env. Geol. 54 197-211.

Doneen L D 1962 The influence of crop and soil on percolating water; In: Proc. 1961 Biennial Conference on Groundwater Recharge, pp. 156-163.

Doneen L D 1964 Notes on water quality in agriculture; Published as a water science and engineering paper 4001, Dept. of Water Sci. and Engg., Univ. of California.

Duraiswami R A 2007 Groundwater conditions in groundwater provinces of eastern Maharashtra: Emerging challenges; In: Recent Developments in Groundwater Resources of Central India (eds) Pophare A M and Malpe D B, Gond. Geol. Mag. Spec. Vol. 11 69-76.

Duraiswami R A 2008 Changing geohydrological scenario in the hard-rock terrain of Maharashtra: Issues, concerns and way forward; In: Changing Geohydrological Scenario in Hard rock Terrain of Peninsular India (ed.) Das S, Geol. Soc. India Memoir 69 86-121.

Eaton F M 1950 Formulas for estimating the drainage and gypsum requirement of irrigation water; Texas Agri. Expt. Sta. Misc. Report III.

El-Naqa A and Al-Shayeb A 2009 Groundwater protection and management strategy in Jordan; Water Resour. Manag. 23 2379-2394; doi: 10.1007/s11269-008-9386-x.

Freeze R A and Cherry J A 1979 Groundwater; Prentice Hall Inc., New Jersey, 604p.

Friedman L C and Erdmann D E 1982 Quality assurance practices for analyses of water and fluvial sediments; 
Tech. Water Resources Inc. Book 5, Chapter A6, US Govt. Printing Office, Washington DC.

GEC 1997 Report of the groundwater resources estimation committee methodology-1997; Ministry of Water Resources, Govt. of India, New Delhi, 107p.

Gibbs R J 1970 Mechanism controlling world water chemistry; Science 170 1088-1090.

Handa B K 1981 Technical report on hydrochemistry, water quality and water pollution in Uttar Pradesh; Central Ground Water Board, Ministry of Agriculture and Irrigation, Govt. of India, 317p.

Harou J J and Lund J R 2008 Ending groundwater overdraft in hydrologic-economic systems; Hydrogeol. J. 16 10391055.

Hem J D 1985 Study and interpretation of the chemical characteristics of natural waters; 3rd edn, USGS Water Supply Paper 2254 175-177.

Johnson C C Jr 1979 Land application of waste: An accident waiting to happen; Groundwater 17 69-72.

Katz B G and Choquete A F 1991 Aqueous geochemistry of sand and gravel aquifers, Northwest Florida; Groundwater 29(1) 47-55.

Kelley W P 1946 Permissible composition and concentration of irrigation waters; In: Proc. Am. Soc. Civil Engg., $607 \mathrm{p}$.

Kelley W P 1951 Alkali soils - their formation properties and reclamation; Reinold Publ. Corp., New York.

Khayat S, Heinz H, Stefan G and Wasim A 2006 Hydrochemical investigation of water from the Pleistocene wells and springs, Jericho area, Palestine; Hydrogeol. J. 14 192-202.

Lloyd J W and Heathcote J A 1985 Natural inorganic hydrochemistry in relation to groundwater: An introduction; Oxford Univ. Press, New York, 296p.

Madnure P, Sirsikar D Y, Tiwari A N, Ranjan B and Malpe D B 2007 Occurrence of fluoride in the groundwaters of Pandharkawada area, Yavatmal Dist., Maharashtra, India; Curr. Sci. 92(5) 675-679.

NEERI 1986 Manual of water and waste water analysis; National Environmental Engineering Research Institute, Nagpur, 340p.

Paliwal K V 1967 Effects of gypsum application on the quality of irrigation water; The Madras Agri. J. 59 646-647.

Pandian K and Sankar K 2007 Hydrogeochemistry and groundwater quality in the Vaippar river basin, Tamilnadu; J. Geol. Soc. India 69 970-982.

Pawar N J 1993 Geochemistry of carbonate precipitation from the groundwaters in the basaltic aquifers: An equilibrium thermo-dynamic approach; J. Geol. Soc. India 41 119-131.

Pawar N J and Nikumbh J D 2007 Mass balance modelling of groundwater from shallow and alluvial aquifers of Behedi basin, District Nasik, Maharashtra; In: Recent Developments in Groundwater Resources of Central India (eds) Pophare A M and Malpe D B, Gond. Geol. Mag. Spec. Vol. 11 23-34.

Pedro G and Siefferman G 1979 Weathering of rocks and formation of soils; In: Review of research on modern problems of geochemistry (ed.) Siegel F R, pp. 39-54.

Piper A M 1944 A graphic procedure in the geochemical interpretation of water analyses; Trans. Am. Geophys. Union 25 914-928.

Piper A M 1953 A graphic procedure in the geochemical interpretation of water analysis; USGS Groundwater Note 12.

Plummer L N and Back W 1980 The mass balance approach: Application to interpreting the chemical evolution of hydrologic systems; Am. J. Sci. 280 130-142.
Pojasek R B 1977 Drinking water quality enhancement through protection; Ann Arbor Science Publishers Inc., Michigan, 614p.

Pophare A M and Dewalkar S M 2007 Groundwater quality in eastern and southeastern parts of Rajura Tahsil, Chandrapur District, Maharashtra; In: Recent Developments in Groundwater Resources of Central India (eds) Pophare A M and Malpe D B, Gond. Geol. Mag. Spec. Vol. 11 119-126.

Raman V 1985 Impact of corrosion in the conveyance and distribution of water; J. Int. Water Works Assoc. XV(11) 115-121.

Richards L A 1954 Diagnosis and improvement of saline and alkali soils; Agri. Handbook 60, US Dept. of Agriculture, Washington DC, 160p.

Rossum J R 1975 Checking the accuracy of water analyses through the use of conductivity; J. Am. Water Works Assoc. 67204.

Ryner J W 1944 A new index for determining amount of calcium carbonates scale formed by water; J. Am. Water Assoc. 36 472-486.

Saini R K, Chakrapani G J and Sen A K 2006 Geochemical studies of groundwater in Saharanpur, Uttar Pradesh; J. Geol. Soc. India 68 50-58.

Schoeller H 1955 Geochemie des eause souterraines; Rev. Inst. Fr. Petrol. 10 230-244.

Schoeller H 1967 Qualitative evaluation of groundwater resources; In: Methods and Techniques of Groundwater Investigations and Development, UNESCO Water Resources Series 33 44-52.

Seaber P R 1962 Cation hydrochemical facies of groundwater in the Englishtown Formation, New Jersey; USGS professional paper 450, article 51.

Sivasankar V, Ramachandramoorthy $\mathrm{T}$ and Chandramohan A 2012 Deterioration of coastal groundwater quality in Island and mainland regions of Ramanathapuram District, southern India; Env. Monit. Assess., doi: 10.1007/s10661-012-2604-2.

Sophocleous M 2003 Environmental implications of intensive groundwater use with special regard to streams and wetlands; In: Intensive Use of Groundwater (eds) Lamas $\mathrm{R}$ and Custodio E, The Netherlands, pp. 93-112.

Sreedevi P D 2002 Hydro-geochemistry of Pageru river basin, Cuddapah District, Andhra Pradesh; In: Proc. 'Hydrology and Watershed Management' I 638645.

Sreedevi P D 2004 Groundwater quality of Pageru river basin, Cuddapah district, Andhra Pradesh; J. Geol. Soc. India 64(5) 619-636.

Tardy Y 1971 Characterization of principal weathering types by geochemistry of water from some European and African crystalline massifs; Chem. Geol 7 $253-271$.

Tijani J 1994 Hydrochemical assessment of groundwater in Moro area, Kwara State, Nigeria; Env. Geol. 24 194202.

Tiwari A N, Nawale V P, Tambe J A and Satya Kumar Y 2008 Correlation of fluoride with bicarbonate in groundwater of exploratory wells in parts of Maharashtra; $J$. Appl. Geochem. 10 93-102.

Tiwari A N, Nawale V P, Tambe J A and Satya Kumar Y 2007 Non-lithological nitrate and chloride causing increase in total dissolved solids in groundwater of shallow basaltic aquifer of Maharashtra; Indian J. Geochem. 22(2) 355-362.

USSL 1954 Diagnosis and improvement of saline and alkali soils; United States Salinity Laboratory Staff, US Dept. of Agriculture Hand Book, 60 160p. 
USSL 1973 Diagnosis and improvement of saline and alkali soils; United States Salinity Laboratory Staff, US Dept. of Agriculture, Hand Book, 60, 2nd edn, 173p.

Walton W C 1970 Groundwater resources evaluation; McGraw-Hill Book Co., New York, 664p.

Weijden C H Van der and Pacheco F A L 2006 Hydrogeochemistry in the Vogue River basin (central Portugal): Pollution and chemical weathering; Appl. Geochem. 21(4) 580-613.
Wilcox L V 1948 The quality of water for Irrigation use; US Dept. Agri., Tech. Bulletin-1962, Washington DC, 19p.

Wilcox L V 1955 Classification and use of irrigation waters; US Dept. of Agriculture, Circular 961.

Zekster S, Loaiciga H A and Wolf J T 2005 Environmental impacts of groundwater overdraft: Selected case studies in the southwestern United States; Env. Geol. 47 396404.

MS received 27 June 2012; revised 10 June 2013; accepted 9 September 2013 